\title{
O Capital Psicológico do Trabalho e a Satisfação e o Comprometimento Organizacional de Professores Universitários de Contabilidade
}

\author{
Juliano Francisco Baldissera \\ Universidade Estadual do Oeste do Paraná \\ Brasil \\ Ivan Rafael Defaveri \\ Universidade Estadual do Oeste do Paraná \\ Brasil \\ Silvana Anita Walter \\ Universidade Estadual do Oeste do Paraná \\ Brasil
}

Data da submissão: 27/03/2018

Data de aceite: 01/06/2018

\section{RESUMO}

Este estudo analisa como se constitui o capital psicológico do trabalho e a satisfação e o comprometimento organizacional de professores universitários de contabilidade. Se trata de uma pesquisa descritiva e qualitativa, por meio da análise de discurso de entrevistas realizadas com 11 professor universitários do curso de ciências contábeis. Os resultados indicam que o capital psicológico parece ser inerente à realidade da profissão de professor. Esses docentes demonstram um estado emocional positivo com a oportunidade de realizar o tipo de trabalho que fazem, por isso, se mostram comprometidos com a instituição. Não são os custos de sair dessa instituição que mantêm esses professores ligados a ela. Continuar nessa instituição é uma forma de retribuir ao que ela já fez por eles, mesmo não sendo uma obrigação, ainda que se sintam injustos caso saíssem de lá.

Palavras-chave: Capital Psicológico; Satisfação no Trabalho; Comprometimento Organizacional.

\begin{abstract}
This study analyzes how the psychological capital of work is constituted and the satisfaction and the organizational commitment of university accounting professors. This is a descriptive and qualitative research, through the discourse analysis of interviews conducted with 11 university professors of the course of accounting sciences. The results indicate that psychological capital seems to be inherent in the reality of the teaching profession. These teachers demonstrate a positive emotional state with the opportunity to perform the type of work they do, so they are committed to the institution. It is not the costs of leaving this institution that keep these teachers attached to it. To continue in this institution is a way of repaying what she has already done for them, even though it is not an obligation, even if they feel unfair if they leave.
\end{abstract}

Keywords: Psychological Capital; Job Satisfaction; Organizational Commitment. 


\section{INTRODUÇÃO}

A docência é uma carreira que exige do indivíduo a apropriação do planejamento e do desenvolvimento, em que é necessário investir em competências tais como know-how (o conhecimento, a técnica), o know-why (as motivações para o exercício do trabalho) e o knowwhom (a rede de relacionamento) (LACOMBE, 2002, BOUZADA; KILIMNIK; OLIVEIRA, 2012). O capital psicológico do trabalho está relacionado à capacidade de os indivíduos se adaptarem às alterações do ambiente do trabalho (LUTHANS et al., 2007; FERGUSON; REIO, 2010).

A satisfação no trabalho pode ser visualizada como um estado emocional agradável resultante da avaliação que o indivíduo faz de seu trabalho (LOCKE, 1969; SANTOS; BEUREN, 2017). O comprometimento organizacional está relacionado à identificação do colaborador com a organização e com os seus objetivos (MOWDAY; STEERS; PORTER, 1979), o qual, por sua vez, pode ser segregado em três componentes distintos: comprometimento afetivo, comprometimento normativo e comprometimento calculativo (REGO, 2002; MEYER; ALLEN, 1991).

A satisfação e o comprometimento organizacional de docentes desempenham um papel importante no alcance de objetivos, no desempenho educacional e na qualidade de ensino (BULUC; GUNES; 2014; SANTOS; BEUREN, 2017). A dinamicidade das organizações e a complexidade que as tarefas têm exigido mostram a necessidade de contar com trabalhadores com capital psicológico elevado, considerando níveis de esperança, de otimismo, de capacidade de suportar as pressões do dia-a-dia e de atingir seus objetivos (LUTHANS; LUTHANS; LUTHANS, 2004; SOUZA; SIQUEIRA; MARTINS, 2015).

É necessário desenvolver, dentro do ambiente de trabalho, um relacionamento de amizade, de respeito e de confiança (EISENBERGER et al., 1986; SOUZA; SIQUEIRA; MARTINS, 2015), para que os empregados desenvolvam vínculos positivos com o trabalho e a organização, consequentemente, melhorando os níveis de satisfação e de comprometimento organizacional (SIQUEIRA; PADOVAM, 2008; SOUZA; SIQUEIRA; MARTINS, 2015).

O construto motivacional positivo implica no sentimento de realização que envolve um estado cognitivo e que é persistente no tempo, apresentando natureza motivacional e social (BAKKER et al., 2008; LLORENS et al., 2007; SCHAUFELI; BAKKER, 2004). O capital psicológico é intangível (LUTHANS; LUTHANS; LUTHANS, 2004; CAVALCANTE; SIQUEIRA; KUNIYOSHI, 2014), está relacionado à quatro dimensões psicológicas: autoeficácia, esperança, otimismo e resiliência (LUTHANS; LUTHANS; LUTHANS, 2004). 
Percebe-se que outros estudos já trataram sobre o capital psicológico do trabalho (SOUZA; CONCEIÇÃO, 2013; CAVALCANTE; SIQUEIRA; KUNIYOSHI, 2014; SOUZA; SIQUEIRA; MARTINS, 2015; MARCOS; VOGT; CUNHA (2017), outros relacionados à satisfação no trabalho (SANTOS; BEUREN, 2017) e também outros que consideraram o comprometimento organizacional (REGO, 2002; REGO; SOUTO, 2004; SIQUEIRA; GOMIDE JR., 2004; SANTOS; BEUREN, 2017). Entretanto, observa-se que não encontrouse pesquisas que discutiram a relação do capital psicológico do trabalho e da satisfação e o comprometimento organizacional afetivo, calculativo e normativo. Outra constatação é de que, além de não ser dado esse enfoque, não foi visualizado essa temática a partir da percepção dos professores universitários de Contabilidade.

Dessa forma, considerando a necessidade de discutir sobre o tema e avançar com a literatura especializada, tem-se como questão de pesquisa: como se constitui o Capital Psicológico do Trabalho (autoeficácia, esperança, otimismo e resiliência) e a Satisfação e o Comprometimento Organizacional (afetivo, calculativo e normativo) de professores universitários de Contabilidade? Considerando esse problema de pesquisa, pretendeu-se analisar como se constitui o capital psicológico do trabalho (autoeficácia, esperança, otimismo e resiliência) e a satisfação e o comprometimento organizacional (afetivo, calculativo e normativo) de professores universitários de Contabilidade.

Assim, ao identificar as construções psicológicas positivas dos empregados, uma organização pode aprender sobre o capital psicológico desse funcionário, o que permite melhorar assuntos relacionados à treinamento e ao suporte desses indivíduos (AVEY; LUTHANS; JENSEN, 2009; IDRIS; MANGANARO, 2017). Desse modo, diante da necessidade das organizações e da própria sociedade, este trabalho justifica-se pela necessidade de discutir as características psicológicas positivas de professores universitários de Contabilidade para que eles possam assumir enfrentar desafios cada vez mais complexos.

Além desta introdução, o trabalho expõe, no referencial, a literatura que fundamenta o capital psicológico do trabalho e a satisfação e o comprometimento organizacional. A metodologia é apresentada de modo a evidenciar o delineamento proposto para responder ao problema e atingir ao objetivo central. Na análise são apresentados todos os resultados obtidos, e, por fim, na conclusão, são evidenciados os principais resultados e como eles contribuem para o avanço das pesquisas nessa área.

\section{REFERENCIAL TEÓRICO}

\subsection{Capital Psicológico no Trabalho}


Os estudos acadêmicos sobre o comportamento organizacional ao longo dos anos foram direcionados à abordagem de aspectos negativos dos componentes das organizações (LUTHANS, 2002), no entanto, seguindo uma linha motivacional iniciada por autores de bestsellers, os próprios acadêmicos deram início a uma linha de estudos com vistas a abordar o comportamento organizacional positivo (POLIZZI FILHO, 2011). Dessa forma, uma abordagem positiva das características que compõem o capital psicológico positivo, esse, por sua vez, sendo o fator que direciona os estudos sobre o comportamento organizacional positivo, tomou lugar de destaque na literatura sobre o tema a partir dos estudos de Luthans (2002) (POLLIZI FILHO, 2011).

O estudo do capital psicológico leva os estudiosos a compreender como os processos das organizações são transformados e impactados por meio do entendimento das quatro capacidades psicológicas elencadas por Luthans e Youssef (2004), a saber: autoeficácia, a esperança, o otimismo e a resiliência (POLIZZI FILHO, 2011). O termo "capital” utilizado aqui provém do fato desse capital ser um conjunto de propensões e motivações inerentes ao indivíduo, acumuladas a partir das quatro construções psicológicas positivas mencionadas (LUTHANS et al., 2007).

Esses quatros constructos formam o capital psicológico positivo (LUTHANS et al., 2007), o que corresponde a uma fonte de vantagem competitiva para as organizações atuais (LUTHANS; YOUSSEF, 2004), ao ser considerado como fonte de capital intelectual, necessário para a adaptação do indivíduo ao ambiente de trabalho (LUTHANS et al., 2007).

Essa vantagem competitiva é gerada para as empresas devido ao fato de o capital psicológico positivo representar um fator de evolução pessoal dos indivíduos (YOUSSEF; LUTHANS, 2007), uma vez que proporciona confiança para assumir e colocar o esforço necessário para assumir desafios (autoeficácia), ter pensamento positivo sobre a possibilidade de sucesso no futuro (otimismo), perseverança em direção a metas e busca de novos caminhos para alcançar essas metas (esperança) e capacidade de se sustentar e recompor após problemas e adversidades (resiliência) (LUTHANS et al., 2007).

A autoeficácia corresponde à crença positiva que o profissional tem sobre suas habilidades no trabalho (LUTHANS et al., 2007), tendo sido conceituada por Stajkovic e Luthans (1998) como a convicção ou confiança do empregado em suas habilidades para mobilizar a motivação, recursos cognitivos ou cursos de ação necessários para executar com sucesso uma tarefa específica dentro de um determinado contexto. A eficácia é tratada como um conceito estático, algo inerente ao indivíduo que não se altera ao longo do tempo; entretanto, 
dentro da teoria da psicologia positiva, o conceito de autoeficácia não é descontextualizado, de modo a poder ser desenvolvido e gerenciado no decurso do tempo (LUTHANS, 2002).

Por sua vez, a esperança é definida por Snyder et al. (2002) como o processo de pensar em objetivos, bem como formas de alcançar esses objetivos e a motivação para avançar em direção a eles. Luthans e Youssef (2004) indicam que a esperança é um estado motivacional composto de três caminhos: os objetivos, a agência e os caminhos. O estudo da esperança mostra-se relevante, e seus conceitos aplicáveis ao mercado de trabalho (YOUSSEF; LUTHANS, 2007), dado o papel da esperança na definição de metas, no planejamento de contingências e no remanejamento de recursos (SNYDER et al., 2000). Uma relação pode ser traçada entre essas duas características, uma vez que, de acordo com Snyder et al. (2000), o indivíduo esperançoso tende a apresentar um maior senso de autoeficácia. Esses indivíduos dotados de forte esperança tendem a ser motivados a desenvolver as coisas do seu jeito e a buscar caminhos alternativos para alcançar os seus objetivos (LUTHANS; YOUSSEF, 2004).

O terceiro constructo, o otimismo, considerado por Luthans (2002) como o coração do comportamento organizacional positivo. O otimismo busca explicar eventos positivos por meio de uma visão interna do ser, de forma permanente, relacionando fatores negativos a circunstâncias e a fatores temporários (YOUSSEF; LUTHANS, 2007). Esse otimismo tende a ser um motor que move os indivíduos ao sucesso, dado o seu impacto positivo na saúde física, psicológica e organizacional (LUTHANS, 2002), todavia, o excesso de otimismo pode trazer resultados negativos, uma vez que pode distrair e tirar o foco dos indivíduos das possíveis adversidades futuras (LUTHANS, 2002; LUTHANS et al., 2004).

O quarto componente do capital psicológico é a resiliência, conhecida como a capacidade de alcançar bons resultados frente a ameaças, adaptação e desenvolvimento frente a elas (MASTEN, 2001). Esse conceito indica uma variabilidade na forma como os indivíduos respondem a situações e a experiências semelhantes, tendo em vista a adaptação à cada uma dessas circunstâncias (LUTHANS et al., 2007; DEMO; OLIVEIRA; COSTA, 2017). Luthans et al. (2017) indicam também o fato de, sempre que um indivíduo passa por uma situação adversa, tende a se recompor mais preparado para uma situação semelhante, sendo essa recomposição o fator de resiliência. A resiliência é, portanto, o estágio final do capital psicológico, resultante dos demais constructos na forma de reconstrução do indivíduo (LUTHANS et al., 2007; DEMO; OLIVEIRA; COSTA, 2017).

Esses constructos, quando aplicados conjuntamente, compartilham de mecanismos de motivação (YOUSSEF; LUTHANS, 2007) capazes de gerar benefícios para a organização como um todo (VILAÇA; MÓNICO; CASTRO, 2012). Os indivíduos tendem a apresentar 
esses constructos em conjunto, já que indivíduos esperançosos tendem a ter uma melhor visão sobre suas capacidades, uma melhor perspectiva de futuro e também uma melhor adaptação a situações adversas (LUTHANS et al., 2007).

Dessa forma, não só o capital psicológico tem a capacidade de influenciar no desempenho dos indivíduos no trabalho (LUTHANS, 2002; LUTHANS et al., 2004; LUTHANS; YOUSSEF, 2004; LUTHANS et al., 2007), mas também na satisfação dos indivíduos no ambiente de trabalho.

\subsection{Satisfação no Trabalho}

Um dos fatores relacionados ao capital psicológico de profissionais é a satisfação no trabalho, conceituada como sendo um sentimento agradável proveniente de uma avaliação positiva feita pelo indivíduo do seu trabalho (SANTOS; BEUREN, 2017), ou seja, representa basicamente como as pessoas se sentem com relação ao seu trabalho (ALTAHAYNEH; KHASAWNEH; ABEDALHAFIZ, 2014).

Santos e Beuren (2017) indicam ainda o fato de a satisfação representar o quanto um indivíduo está feliz com o seu trabalho e com a execução de suas atividades, representando, acima de tudo, o prazer do profissional com o trabalho exercido (ALTAHAYNEH; KHASAWNEH; ABEDALHAFIZ, 2014).

Esse sentimento se dá sobretudo devido a cinco aspectos específicos, que são os colegas, o salário, as promoções, o trabalho e a chefia (PAULA; QUEIROGA, 2015). Esses fatores indicam a satisfação dos profissionais uma vez que criam um clima organizacional favorável ao indivíduo, de modo que perceba no seu trabalho a possibilidade de valorização de seus objetivos e da realização de suas metas (ANDRADE et al., 2015).

A satisfação é, então, um conjunto de reações emocionais complexas, sendo proveniente, sobretudo, da percepção pelo profissional daquilo que lhe é oferecido no trabalho em comparação com suas expectativas (RUEDA, 2015). Esse sentimento tem a capacidade de influenciar a vida dos indivíduos de modo a eles apresentarem um melhor desempenho individual em suas tarefas (PAIVA et al., 2017).

Ao mesmo tempo que a satisfação é um conceito composto por diversos fatores dentro da organização, também pode ser considerado como um conceito global de afinidade do profissional com seu local de trabalho (ROELEN; KOOPMANS; GROOTHOFF, 2008).

Essa afinidade com o trabalho é considerada o fator que liga a satisfação no trabalho ao comprometimento organizacional, tendo vários estudos já buscando identificar essa relação (SANTOS; BEUREN, 2017). Nessa perspectiva, a próxima seção fala sobre o comprometimento organizacional dos funcionários com a organização. 


\subsection{Comprometimento Organizacional}

A discussão sobre o comprometimento organizacional teve início com o trabalho seminal de Porter et al. (1973), que estudaram como o comprometimento dos empregados nas organizações afetava sua satisfação no trabalho. Esses autores definem o comprometimento organizacional como a identificação e o envolvimento de um indivíduo com uma organização em específico (PORTER et al., 1973).

Esse comprometimento apresenta três principais características, que são a de comprometimento afetivo, comprometimento calculativo e comprometimento normativo (MEYER; ALLEN, 1991). O comprometimento afetivo refere-se ao estado de identificação e de envolvimento com a organização (MEYER; ALLEN, 1991). O comprometimento calculativo representa os custos percebidos pelo profissional caso ele saia da organização (MEYER et al., 2002), já o comprometimento normativo indica que os funcionários de uma organização permanecem nessa organização devido a um senso de dever, de obrigação por trabalhar naquele lugar (ALBASSAMI; AL-MESHAL; BAILEY, 2015).

O comprometimento afetivo tem um importante papel no aspecto do crescimento do profissional na carreira (CASIMIR; NG; OOI, 2014), uma vez que esse tipo de comprometimento tem como principal enfoque avaliar a visão do indivíduo com relação à capacidade de a empresa suprir as suas necessidades de trabalho (WANG et al., 2014). Esse tipo de comprometimento assume forma de dedicação e de lealdade à empresa e a seus princípios, tomados pelo indivíduo como sendo os seus próprios (RHOADES; EISENBERGER; AIMELI, 2001). Quando o funcionário não consegue desenvolver satisfatoriamente o comprometimento afetivo com a organização, o resultado inclui a exaustão profissional e o aumento da intenção de transferência do funcionário (LAPOINTE; VANDENBERGHE; BOUDRIAS, 2013), o que leva à redução do comprometimento calculativo.

Esse comprometimento, por sua vez, está diretamente associado à avaliação de custos de permanência na organização (SALLAN et al., 2010), ao considerar se os sacrifícios assumidos na saída do trabalho superar os benefícios da permanência (SULIMAN; ILES, 2000). Esse tipo de comprometimento tem uma característica diferente dos demais com relação ao desempenho no trabalho, uma vez que não interfere diretamente na flexibilidade e na dedicação do profissional à empresa (SULIMAN; ILES, 2000). No entanto, um funcionário com baixo comprometimento calculativo tende a ter uma menor evolução na sua produtividade, uma vez que tem baixa preocupação com a sua manutenção na empresa (GONG; CHANG; XIN, 2009). 
Dessa forma, o comprometimento afetivo e calculativo, apesar de diferirem significativamente entre si (GONG; CHANG; XIN, 2009; SALLAN et al., 2010), se mostram relacionados, uma vez que o profissional com baixa ligação afetiva com o trabalho tende a não desconsiderar uma troca de organização (SULIMAN; ILES, 2000), ao mesmo tempo em que um profissional que considere mais vantajosa uma saída da empresa tem dificuldades em criar laços afetivos com a mesma (GONG; CHANG; XIN, 2009).

A terceira característica do comprometimento organizacional é o comprometimento normativo (MEYER et al., 2002), definido como um sentimento de obrigação do funcionário para com a empresa (GONZÁLEZ; GUILLÉN, 2008). Jaros (2017) critica a consideração do comprometimento normativo como uma dimensão válida do comprometimento organizacional, ao considerar a sua construção redundante com relação a algumas características dos comprometimentos afetivo e calculativo. Por outro lado, autores como Vandenberghe, Mignonac e Manville (2014) consideram o comprometimento normativo como uma dimensão complementar as demais, uma vez que os fatores que levam o indivíduo a se sentir obrigado em permanecer na organização envolvem desde uma ligação afetiva a esta, até o medo de não conseguir um emprego melhor (VANDENBERGHE; MIGNONAC; MANVILLE, 2014; JAROS, 2017).

Desse modo, as três dimensões atuam como antecedentes e consequentes do comprometimento organizacional (MEYER et al., 2002), ou seja, a identificação do indivíduo com uma organização (PORTER; STEERS; BOULIAN, 1973). De acordo com Vandenberghe, Mignonac e Manville (2014), essas três características do comprometimento são complementares, de modo ao baixo nível de comprometimento de uma das dimensões afetar também as demais. Dessa forma, apenas apresentando todas as três características do comprometimento, o comprometimento afetivo, o calculativo e o normativo, considera-se o indivíduo como efetivamente comprometido ao trabalho (IDRIS; MANGANARO, 2017).

\section{METODOLOGIA}

Esta pesquisa pode ser classificada como um estudo qualitativo, pois proporciona melhor compreensão de um cenário, bem como a percepção de um fato (RAUPP; BEUREN, 2009), neste caso, mostra o relacionamento entre o capital psicológico, a satisfação no trabalho e comprometimento organizacional de professores universitários de Contabilidade.

Como meio de operacionalizar o estudo, foram realizadas entrevistas semiestruturadas com professores universitários do curso de ciências contábeis, com formação e atuação em diversas disciplinas, atuantes em faculdades e universidades do estado do Paraná. Foram 
entrevistados 11 professores, sendo cinco deles atuantes em uma instituição de ensino superior pública, com campus nas regiões oeste e sudoeste do Paraná, e também seis professores atuantes em instituições privadas localizadas regiões oeste, sudoeste e noroeste do Paraná.

O roteiro de entrevista foi elaborado de acordo com a adaptação dos questionários referentes ao capital psicológico, presente no livro "Novas Medidas do Comportamento Organizacional: Ferramentas de diagnóstico e de Gestão”, de Siqueira (2014), no questionário sobre satisfação no trabalho e comprometimento organizacional, presentes em Siqueira (2008), no livro "Medidas do comportamento organizacional: ferramentas de diagnóstico e de gestão", além de um bloco de questões para identificar o perfil dos respondentes.

A Tabela 1 mostra o constructo do roteiro de entrevista empregado, de forma a demonstrar como esse roteiro foi estruturado, de acordo com as dimensões de cada categoria de análises, suas definições e a quantia de perguntas feitas para cada uma dessas dimensões.

Tabela 1: Constructo da pesquisa

\begin{tabular}{|c|c|c|c|}
\hline Dimensão & Definição & Autores & Quantidade \\
\hline PERFIL & Identificação do perfil dos professores & Elaborado pelos autores & 10 questões \\
\hline \multicolumn{4}{|c|}{ CAPITAL PSICOLÓGICO } \\
\hline Autoeficácia & $\begin{array}{l}\text { Acreditar na sua capacidade de mobilizar } \\
\text { recursos cognitivos para obter resultados } \\
\text { específicos }\end{array}$ & $\begin{array}{l}\text { Stajkovic e Luthans (1998), Luthans } \\
\text { et al. (2007) Siqueira (2014). }\end{array}$ & 7 questões \\
\hline Esperança & $\begin{array}{l}\text { Ter a força de vontade e caminhos para atingir } \\
\text { seus objetivos }\end{array}$ & $\begin{array}{l}\text { Snyder et al. (2002), Luthans e } \\
\text { Youssef (2004), Siqueira (2014). }\end{array}$ & 5 questões \\
\hline Otimismo & $\begin{array}{l}\text { Ter o estilo explicativo que atribui eventos } \\
\text { positivos para o interior, permanente e causas } \\
\text { penetrantes }\end{array}$ & $\begin{array}{l}\text { Luthans (2002), Luthans e Youssef } \\
\text { (2004), Youssef e Luthans (2007), } \\
\text { Siqueira (2014) }\end{array}$ & 5 questões \\
\hline Resiliência & $\begin{array}{l}\text { Ter a capacidade de se recompor após uma } \\
\text { adversidade, fracasso ou mesmo parecendo } \\
\text { boas as mudanças devastadoras }\end{array}$ & $\begin{array}{l}\text { Masten (2001), Luthans et al. (2007), } \\
\text { Siqueira (2014) }\end{array}$ & 6 questões \\
\hline \multicolumn{4}{|c|}{ SATISFAÇÃO NO TRABALHO } \\
\hline Satisfação & $\begin{array}{l}\text { Estado emocional agradável resultante da } \\
\text { avaliação que o indivíduo faz de seu trabalho }\end{array}$ & $\begin{array}{l}\text { Locke (1969), Santos e Beuren } \\
\text { (2017), Siqueira (2008). }\end{array}$ & 9 questões \\
\hline \multicolumn{4}{|c|}{ COMPROMETIMENTO ORGANIZACIONAL } \\
\hline $\begin{array}{l}\text { Comprometimento } \\
\text { afetivo }\end{array}$ & $\begin{array}{l}\text { No comprometimento afetivo, o empregado se } \\
\text { sente emocionalmente ligado e envolvido com } \\
\text { a organização }\end{array}$ & $\begin{array}{l}\text { Meyer e Allen (1991), (Casimir, Ng e } \\
\text { Ooi (2014), Siqueira (2008) }\end{array}$ & 11 questões \\
\hline $\begin{array}{l}\text { Comprometimento } \\
\text { Calculativo }\end{array}$ & $\begin{array}{l}\text { O empregado se mantém ligado à instituição } \\
\text { devido ao reconhecimento dos custos } \\
\text { associados com a sua saída }\end{array}$ & $\begin{array}{l}\text { Meyer e Allen (1991), Sallan et al. } \\
\text { (2010), Siqueira (2008) }\end{array}$ & 10 questões \\
\hline $\begin{array}{l}\text { Comprometimento } \\
\text { normativo }\end{array}$ & $\begin{array}{l}\text { O empregado sente que deve permanecer na } \\
\text { instituição, ou seja, apresenta um estado } \\
\text { psicológico de obrigacão. }\end{array}$ & $\begin{array}{l}\text { Meyer e Allen (1991), Vandenberghe, } \\
\text { Mignonac e Manville (2014), Siqueira } \\
\text { (2008) }\end{array}$ & 5 questões \\
\hline
\end{tabular}

Fonte: Elaborada pelos autores (2017).

Os professores foram contatados via e-mail, marcando-se data e horário para entrevistas, as quais foram gravadas no formato " $\mathrm{m} 4 \mathrm{a}$ " e posteriormente transcritas de forma literal com uso do Ms Word®. As entrevistas transcritas foram organizadas para análise com o uso do software Atlas.ti. 
As informações coletadas nas entrevistas foram analisadas por meio da análise de discurso, teoria que, a partir da fala dos interlocutores, busca estabelecer relações entre situações do mundo real, afim de conhece-las com profundidade (NOGUEIRA, 2001). Dessa forma, são analisadas as falas dos professores universitários participantes da pesquisa a fim de estabelecer um direcionamento de seu discurso, de modo a identificar se as questões da satisfação no trabalho, do comprometimento a organização e do capital psicológico, isto é, do seu senso de confiança, perspectivas e capacidade de recomposição, estão inter-relacionados, de modo a contribuírem mutuamente entre si para a construção da identidade profissional desses professores.

Dentre as limitações do estudo pode-se citar o fato de todos os professores atuarem em uma região geográfica específica, fato que poderia interferir em suas respostas, uma vez que fatores culturais dessa região podem influenciar no seu relacionamento com as instituições nas quais trabalham. Outra limitação poderia ser decorrente do fato de que os professores de instituição pública serem todos vinculados a uma mesma instituição, haja vista que as políticas e cultura organizacional dessa instituição podem ter relação com a forma como esses professores a veem.

\section{DESCRIÇÃO E ANÁLISE DOS RESULTADOS}

\subsection{Perfil dos Respondentes}

Realizou-se um levantamento de características relacionados aos entrevistados, como gênero, idade, tempo de atuação como professor, tempo de atuação como professor na instituição que atualmente leciona, maior nível de titulação, instituição, vínculo com a universidade e se possui outra atividade além da docência. Dessa forma, tem-se a Tabela 2 a seguir.

Tabela 2 - Perfil dos Entrevistados

\begin{tabular}{|c|c|c|c|c|c|c|c|c|}
\hline Entrevistado & Gênero & Idade & $\begin{array}{c}\text { Tempo } \\
\text { Professor }\end{array}$ & $\begin{array}{c}\text { Tempo } \\
\text { Instituição }\end{array}$ & Titulação & Instituição & Vínculo & $\begin{array}{c}\text { Outra } \\
\text { atividade }\end{array}$ \\
\hline Professor 1 & $\mathrm{~F}$ & 24 & 1,5 anos & 2 meses & Mestre & Privada & Parcial & Sim \\
\hline Professor 2 & M & 48 & 8 anos & 6 anos & Especialista & Privada & Parcial & Não \\
\hline Professor 3 & M & 40 & 5 anos & 5 anos & Especialista & Privada & Parcial & Sim \\
\hline Professor 4 & $\mathrm{M}$ & 46 & 14 anos & 12 anos & Doutor & Pública & Integral & Não \\
\hline Professor 5 & $\mathrm{~F}$ & 29 & 2,5 anos & 2,5 anos & Especialista & Privada & Parcial & Não \\
\hline Professor 6 & $\mathrm{~F}$ & 46 & 5 anos & 5 anos & Mestre & Privada & Parcial & Sim \\
\hline Professor 7 & M & 32 & 4,5 anos & 4,5 anos & Mestre & Pública & Integral & Sim \\
\hline Professor 8 & $\mathrm{M}$ & 57 & 25 anos & 25 anos & Doutor & Pública & Integral & Não \\
\hline Professor 9 & $\mathrm{M}$ & 27 & 4 anos & 4 anos & Especialista & Privada & Parcial & Sim \\
\hline Professor 10 & $\mathrm{M}$ & 39 & 9 anos & 4 anos & Doutor & Pública & Integral & Não \\
\hline Professor 11 & F & 53 & 8 anos & 8 anos & Mestre & Pública & Integral & Não \\
\hline
\end{tabular}

Fonte: Elaborada pelos autores (2017). 
A escolha dos entrevistados foi feita de forma não aleatória, escolhendo aqueles professores que se mostrar acessíveis e dispostos a realizar as entrevistas. De qualquer forma, buscou-se escolher esses sujeitos de modo que houvesse heterogeneidade entre eles. Por isso, assim como se visualiza na Tabela 2, foram feitas entrevistas com quatro professores do sexo feminino e 7 professores do sexo masculino. Além disso, também se buscou tanto professores mais novos, com 24 anos, como aqueles mais velhos, 57 anos. Além disso, outro critério foi o tempo de atuação como professor universitário, em que se buscou escolher aqueles com menor e maior tempo de atuação.

Os níveis de titulação também foram distintos, houveram quatro especialistas, quatro mestres e três doutores. Sendo 6 professores de universidades privadas e cinco professores de universidades públicas. O vínculo desses indivíduos também foi misto, isto é, integral e parcial. Por fim, observou-se que seis professores não possuem outra atividade além da docência e cinco possuem. O tempo médio de entrevistas foi de 44 minutos, o que somou um total de oito horas de gravações. As gravações foram transcritas de forma literal para realizar a análise com o auxílio do software Atlas $T I ®$, o que permitiu analisar cada um dos conceitos.

\subsection{Capital Psicológico do Trabalho}

O capital psicológico do trabalho está associado à capacidade de os indivíduos se adaptarem às alterações do ambiente do trabalho (LUTHANS et al., 2007; FERGUSON; REIO, 2010). Os professores são sujeitos que se deparam com desafios diários na sua profissão, visto que trabalham diretamente com o processo formativo educacional dos acadêmicos.

Uma das características do capital psicológico do trabalho é a autoeficácia. A Tabela 3 apresenta algumas evidências observadas nas entrevistas realizadas com os professores a partir dos diferentes questionamentos realizados, tais como: sua capacidade de resolução de problemas, cumprir as obrigações, dominar as tecnologias, enfrentar desafios, dominar procedimentos novos, realizar tarefas complexas e de ser criativo.

\section{Tabela 3 - Capital Psicológico do Trabalho - Autoeficácia}

\begin{tabular}{|c|c|}
\hline Subcategoria & Entrevistas \\
\hline \multirow{10}{*}{$\begin{array}{l}\text { resolver } \\
\text { problemas }\end{array}$} & acabo postergando a resolução dos problemas (1) \\
\hline & eu sempre estou à disposição para ajudar (2) \\
\hline & procuro manter o equilíbrio, não me exaltar, não me expor diante os alunos (3) \\
\hline & Tem um pouco de facilidade por um lado e um pouco de dificuldade por outro (4) \\
\hline & Eu me vejo com capacidade de resolver problemas (6) \\
\hline & $\begin{array}{l}\text { as dificuldades encontradas no decorrer do trabalho de docente eu percebi que nos primeiros dois anos eram bem difíceis, } \\
\text { eu tinha adaptações bastante difíceis, nos primeiros dois anos e meio mas depois que acabei superando essas dificuldades } \\
\text { (7) }\end{array}$ \\
\hline & $\begin{array}{l}\text { o profissional das sociais aplicadas ele tem que ter essa condição de administrar conflitos, porque sistemas de empresas } \\
\text { você tá o tempo todo envolvido com pessoas, pessoas com opiniões diferentes, com aspirações diferentes (8) }\end{array}$ \\
\hline & tenho capacidade ampla de resolver os problemas (9) \\
\hline & eu sou bem flexível pra resolver problemas, na base do dialogo eu acho que é o melhor caminho (10) \\
\hline & estou sempre um pouco em atraso com as obrigações (4) \\
\hline
\end{tabular}




\begin{tabular}{|c|c|}
\hline \multirow[t]{4}{*}{$\begin{array}{l}\text { cumprir as } \\
\text { obrigações }\end{array}$} & $\begin{array}{l}\text { as obrigações básicas, que são obrigatórias, pelos prazos de sistemas, de feedback pros alunos, de provas, eu tenho levado } \\
\text { isso a rigor ( } 7 \text { ) }\end{array}$ \\
\hline & eu consigo cumprir as obrigações com certa tranquilidade (8) \\
\hline & $\begin{array}{l}\text { Normalmente a gente tenta cumprir com todas as obrigações que a gente tem no trabalho (...) desenvolver mais de uma } \\
\text { função (...) trabalhar (...) dificuldade (9) }\end{array}$ \\
\hline & Me considero sim (...) basta a gente ajeitar as situações, momento a momento (11) \\
\hline \multirow{3}{*}{$\begin{array}{l}\text { dominar a } \\
\text { tecnologia }\end{array}$} & eu não me vejo como inovador (2) \\
\hline & utilizo as tecnologias na medida do possível (8) \\
\hline & eu não domino as tecnologias (11) \\
\hline \multirow{6}{*}{$\begin{array}{l}\text { enfrentar } \\
\text { desafios }\end{array}$} & eu procuro enfrentar esses desafios, encarar e mostrar o melhor, eu gosto muito. Acredito que eles me fortalecem (3) \\
\hline & Os desafios fortalecem, a gente aprende bastante com as próprias turmas (5) \\
\hline & alguns desafios são superados, em termos pedagógicos (7) \\
\hline & eu fiz eu sempre coloquei o corpo e a alma, se eu assumo uma missão, eu me comprometo com ela (8) \\
\hline & a mudança tá todo dia acontecendo (...) a mudança tá todo dia acontecendo (9) \\
\hline & $\begin{array}{l}\text { os desafios são feitos pra serem vencidos, e ao mesmo tempo que tem que ter um pouco de paciência, dar um pouquinho } \\
\text { de corda, esticar, diminuir e sempre tentar ir passando pelos problemas (11) }\end{array}$ \\
\hline \multirow{6}{*}{$\begin{array}{l}\text { dominar os } \\
\text { procedimentos } \\
\text { novos }\end{array}$} & Eu tento me adaptar a eles (1) \\
\hline & eu sou muito aberto para mudanças (2) \\
\hline & tenho que me dedicar continuamente (4) \\
\hline & procedimentos novos tem que ser adaptados com a disciplina (9) \\
\hline & Eu acho que são formas diferentes de a gente avançar, eu acho que é uma coisa boa (10) \\
\hline & $\begin{array}{l}\text { as situações novas são instigantes (...) faz com que o se abrir para o novo instigue a realmente buscar a solução pra aquilo } \\
\text { ou realmente conhecer o que é aquilo (11) }\end{array}$ \\
\hline \multirow{7}{*}{$\begin{array}{l}\text { realizar tarefas } \\
\text { complexas }\end{array}$} & A grande dificuldade é tempo mesmo (1) \\
\hline & Há um certo desgaste, desgaste psicológico, desgaste emocional, desgaste profissional (4) \\
\hline & se eu verificar que é algo que eu não domino, eu não vou (2) \\
\hline & $\begin{array}{l}\text { quando chega esse tipo de dificuldade mais complexas, eu procuro entender pra tentar resolver, é um estágio de } \\
\text { aprendizagem (7) }\end{array}$ \\
\hline & $\begin{array}{l}\text { Desorganização (...) angustia (...) não conseguir resolver principalmente de uma complexidade dessa, isso praticamente } \\
\text { me derruba, mas eu não desisto (8) }\end{array}$ \\
\hline & necessita as vezes um pouco mais de tempo pra pesquisa, e análise (9) \\
\hline & Enfrentar elas, eu enfrento, eu estudo, eu planejo a melhor forma de resolver a situação (10) \\
\hline \multirow[t]{8}{*}{ ser criativo } & Sempre tive dificuldades com criatividade (1) \\
\hline & eu procuro inovar, sempre trazer algo novo para os alunos (3) \\
\hline & Eu me considero um professor criativo (4) \\
\hline & Eu acredito que eu utilizo muito, sim, a criatividade (6) \\
\hline & pode ser que eu tenha criatividade em outras áreas que não sejam no trabalho (8) \\
\hline & Sim (...) utiliza alguns meios que a gente aprendeu na pós-graduação e até no mestrado (...) chama a atenção do aluno (9) \\
\hline & $\begin{array}{l}\text { Não, eu não me acho criativo (...) o que a gente faz na construção de artigos não sei se chega a ser tanto, a gente constrói } \\
\text { um pouquinho a cada dia, mas ser criativo é muito mais do que isso (10) }\end{array}$ \\
\hline & De uma certa forma sim (11) \\
\hline
\end{tabular}

Fonte: Elaborada pelos autores (2017).

Observa-se que existe uma realidade distinta quando questionados sobre a capacidade de resolução de problemas. Percebe-se que existe a característica de procrastinação (1), outros se mostraram à disposição (2), buscam ser flexíveis e manter um equilíbrio (3 e 10), demonstrando que existe uma certa facilidade em superá-los (4, 6 e 9). Essas diferentes percepções podem caracterizar uma fonte de vantagem competitiva para as organizações (LUTHANS; YOUSSEF, 2004), permite que o indivíduo se adapte ao ambiente de trabalho (LUTHANS et al., 2007).

Já no que se refere a cumprir as obrigações, os entrevistados demonstram um pouco de dificuldades (4, 7 e 9), enquanto outros consideram superar esses desafios de forma tranquila (8 e 11). A realidade desses professores é uma das justificativas de algumas dificuldades em cumprir com suas obrigações, visto que existe um grande nível de obrigações e, às vezes, eles desenvolvem até mais de uma função ou outra atividade além da docência, o que prejudica.

A capacidade dos professores em dominar as tecnologias também é frágil (2, 8 e 11). Eles não se veem como inovadores, utilizando-as na medida do possível. A docência exige dos 
professores a apropriação do planejamento e do desenvolvimento, em que é necessário investir no conhecimento, na técnica, nas motivações para o exercício do trabalho e também na própria rede de relacionamento (LACOMBE, 2002, BOUZADA; KILIMNIK; OLIVEIRA, 2012). Por isso, existem diferentes desafios que esses indivíduos devem superar; eles observam esses desafios como uma forma de os deixar mais forte (3, 5 e 11), as motivações intrínsecas e extrínsecas caracterizam esses profissionais (8, 7 e 9).

Os procedimentos que surgem são encarados de forma aberta (2) em que se percebe a necessidade de se adaptar, dedicar continuamente (1, 4 e 9). Esses procedimentos são observados como uma coisa boa e instigantes (10 e 11), os quais permitem avançar na profissão. A atuação docente é uma realidade complexa e os desafios também. Os professores mostram dificuldade (1), desgaste (4), desorganização e angústia (8) em superar essas adversidades, entretanto, buscam superá-las a partir de planejamento, de análise e de estudo mais profundo (7, 8, 9 e 10). A criatividade é algo que deve relativizado, alguns entendem que são criativos $(3,4,6,9$ e 11$)$, outros entendem que não (1, 8 e 10).

Os professores, assim como (LUTHANS et al., 2007) caracteriza a autoeficácia, demonstram confiança para assumir e colocar o esforço necessário para assumir desafios, visto que eles demonstram aptidão para resolução de problemas, enxergam os desafios como uma forma de os deixar mais forte, encarando novos procedimentos como uma coisa e instigante. Assim, percebe-se que eles demonstram a convicção ou a confiança em suas habilidades para mobilizar a motivação, recursos cognitivos ou ações para desempenhar as tarefas que envolvem a atuação docente (STAJKOVIC; LUTHANS, 1998).

Outra característica relacionada ao capital psicológico é a esperança. Buscou-se visualizar a capacidade dos professores de ter força de vontade e buscar caminhos para atingir os seus objetivos (LUTHANS; YOUSSEF, 2004). A Tabela 4 demonstra algumas das constatações observadas no que se aos questionamentos: se eles consideram seu conhecimento, energia e experiência suficiente, se eles esperam realizar seus sonhos e se eles se consideram capazes de descobrir caminhos para atingir seus objetivos.

\section{Tabela 4 - Capital Psicológico do Trabalho - Esperança}

\begin{tabular}{|c|c|}
\hline Subcategorias & Entrevistas \\
\hline \multirow{8}{*}{$\begin{array}{l}\text { ter } \\
\text { conhecimento } \\
\text { suficiente }\end{array}$} & $\begin{array}{l}\text { não sei se existe algum dia na docência que você chega e é preparado para tudo e capacitado para tudo e o conhecimento } \\
\text { é suficiente (1) }\end{array}$ \\
\hline & Eu nunca acho que meu conhecimento é suficiente (2) \\
\hline & Professor tem que estar em constante busca do conhecimento (3) \\
\hline & a gente não sabe muita coisa e que a gente tem muita coisa para aprender (5) \\
\hline & eu não acredito que o meu conhecimento é suficiente para dar aula na semana que vem, por exemplo (6) \\
\hline & Eu acho que também é parcial, falta mais, pra crescer (7) \\
\hline & Não (...) eu tenho eu buscar muito, ouvir muito, discutir muito, aprender muito (8) \\
\hline & $\begin{array}{l}\text { o conhecimento que a gente tem hoje ele não é suficiente pra crescer, tem que correr atrás, por causa que a mudança é } \\
\text { diária (9) }\end{array}$ \\
\hline
\end{tabular}




\begin{tabular}{|c|c|}
\hline & $\begin{array}{l}\text { Como docente nada é suficiente (...) o aprendizado, a docência não se aprende com o mestrado, não se aprende com o } \\
\text { doutorado, se aprende com a sala de aula, com o dia a dia, com aquilo que aparece na tua frente (11) }\end{array}$ \\
\hline \multirow{8}{*}{$\begin{array}{l}\text { realizar meus } \\
\text { sonhos }\end{array}$} & Eu tenho uma perspectiva de uma realização dos sonhos/objetivos (1) \\
\hline & Eu não sou pessimista (2) \\
\hline & Eu acredito que esses sonhos serão realizados (3) \\
\hline & $\begin{array}{l}\text { na docência eu invisto no meu projeto de formação pessoal e profissional (...) eu me considero uma pessoa muito } \\
\text { realizada, muito feliz, muito grata (4) }\end{array}$ \\
\hline & $\begin{array}{l}\text { Eu já me realizo em termos profissionais, que eu realmente gosto, que é algo muito gratificante para mim, poder ajudar } \\
\text { as pessoas e pensar na educação do mundo e tentar contribuir de alguma forma para tentar melhorar de alguma forma } \\
\text { isso (5) }\end{array}$ \\
\hline & possibilidade de atingir metas e sonhos é alta (9) \\
\hline & eu acho que é possível, eu acho que com o tempo, com trabalho (10) \\
\hline & $\begin{array}{l}\text { eu tenho sempre uma premissa comigo, de que os sonhos são feitos para serem sonhados, porém eu me pauto muito } \\
\text { com os pés no chão (11) }\end{array}$ \\
\hline \multirow{2}{*}{$\begin{array}{l}\text { ter energia } \\
\text { suficiente }\end{array}$} & eu percebo que a minha cabeça ela está mais lenta, o meu corpo está mais cansado, sim. Mas eu quero reverter (6) \\
\hline & A energia se busca no dia a dia (11) \\
\hline \multirow{5}{*}{$\begin{array}{l}\text { ter experiência } \\
\text { suficiente }\end{array}$} & Eu acredito que a experiência que eu tenho para um momento ela é suficiente (6) \\
\hline & $\begin{array}{l}\text { Não (...) a minha experiência na nossa área, na parte técnica que eu tive fora daqui, ela é muito importante, } \\
\text { principalmente pra gente trazer o aluno pro contexto do conteúdo que a gente tá discutindo ( } 8 \text { ) }\end{array}$ \\
\hline & $\begin{array}{l}\text { Hoje eu digo que conhecimento que nós temos ele dá a possibilidade de trabalhar na área docente, mas a busca por } \\
\text { novos conhecimentos vai te ajudar muito na aplicação em sala de aula, então o que a gente tem de conhecimento tem } \\
\text { que ser sempre aprimorado (9) }\end{array}$ \\
\hline & $\begin{array}{l}\text { a experiência, eu acho que ela é suficiente, mas a gente sempre tem que ir atrás, porque a gente precisa não se ater só } \\
\text { ao que aprendeu (10) }\end{array}$ \\
\hline & $\begin{array}{l}\text { dizer assim eu sou experiente, é muito relativo, porque hoje a gente tá com uma disciplina, amanhã está com outra } \\
\text { disciplina então tudo isso faz com que novos estudos nessa disciplina que é colocada na mão da gente (11) }\end{array}$ \\
\hline $\begin{array}{l}\text { atingir meus } \\
\text { objetivos }\end{array}$ & eu acredito que você sempre tem que estar inovando, ter um plano B (7) \\
\hline
\end{tabular}

A partir das entrevistas, é possível perceber que a realidade da profissão docente é que o conhecimento não é suficiente $(1,2,3,5,6,7,8,9$ e 11). Professores atuam no processo educacional dos acadêmicos, para eles o conhecimento é algo que está sempre mudando, sempre em evolução, o que justifica entender a percepção que não existe a ideia de um dia este conhecimento atinja seu ápice.

Os professores têm esperança que seus sonhos serão realizados no trabalho $(1,2,3,4,5$, 9, 10 e 11). Percebe-se que eles têm a motivação para avançar em direção aos seus sonhos (SNYDER et al., 2002), são dotados de esperança e, por isso, motivados a desenvolver as coisas (LUTHANS; YOUSSEF, 2004), o que se justifica visto que esses professores investem nos projetos de formação pessoal e profissional (4) e consideram a profissão como algo gratificante (5).

A esperança de atingir os seus objetivos é enfraquecida pela energia que consome a atuação docente. Professores se percebem mais cansados (6), mas tentar buscar essa energia no dia a dia (11), já que consideram a profissão como gratificante.

Não muito diferente do conhecimento, a experiência desses profissionais deve ser relativizada (11). Alguns entendem que a experiência que têm é suficiente (6 e 10), outros não (8 e 9). Os entrevistados comentam que a experiência é algo que afeta a esperança de atingir seus objetivos, visto que essa experiência é que permite buscar o aluno para o contexto do conteúdo ( 8 e 9), ao mesmo tempo que mencionam a necessidade de estar sempre se 
aprimorando e evoluindo (9 e 10). Para descobrir caminhos para atingir os objetivos é necessário sempre estar inovando (7), assim como menciona Luthans e Youssef (2004).

Portanto, percebe-se que os professores têm uma percepção positiva relacionada à esperança, acreditam que seus sonhos serão realizados e, para isso, buscam descobrir caminhos para atingir os seus objetivos e metas. Apesar de não ter sido realizado um teste estatístico como uma regressão ou correlação, existe o pressuposto teórico que os indivíduos esperançosos tendem a apresentar também um maior senso de autoeficácia (SNYDER et al., 2000). Assim, espera-se que aqueles professores que tenham essa percepção de autoeficácia também acreditam nos seus sonhos e tenham esperança de atingi-los.

O otimismo é outra característica positiva do capital psicológico. É quando o indivíduo tem o estilo explicativo que atribui eventos positivos para o interior (LUTHANS; YOUSSEF, 2004). A Tabela 5 divulga algumas constatações observadas no que se refere às percepções dos professores se eles acreditam que tudo dará certo, que dias melhores virão e que se o amanhã será melhor, e, por fim, se esperam ter planos para o futuro no trabalho.

Tabela 5 - Capital Psicológico do Trabalho - Otimismo

\begin{tabular}{|c|c|}
\hline Subcategoria & Entrevista \\
\hline \multirow[t]{8}{*}{ tudo dará certo } & expectativa que tudo dará certo (1) \\
\hline & $\begin{array}{l}\text { Eu acho que tudo tem solução, então se tiver um problema, é só se acalmar e esperar o dia seguinte que as coisas vão } \\
\text { melhorar e a poeira vai abaixar (2) }\end{array}$ \\
\hline & $\begin{array}{l}\text { Eu sou otimista em relação ao trabalho, eu sou otimista em relação a algumas pessoas e sou pessimista em relação } \\
\text { algumas coisas (4) }\end{array}$ \\
\hline & tenho sempre o pensamento positivo (5) \\
\hline & $\begin{array}{l}\text { Sim (...) eu sempre saio de casa fazendo uma oração e na certeza que eu estou na proteção divina e que eu vou conseguir } \\
\text { dar uma boa aula (6) }\end{array}$ \\
\hline & tudo pode dar certo, se você fizer bem feito com boas intenções (7) \\
\hline & $\begin{array}{l}\text { Sim (...) eu só penso em atingir com sucesso as atividades que eu pretendo, assim, em nenhum momento mesmo } \\
\text { naqueles de maior angustia que eu tenho eu me deparo com uma situação de eu pensar que não vou atingir (8) }\end{array}$ \\
\hline & Querer acreditar sim, mas que realmente vai dar certo é difícil, não tem como a gente prever o lá na frente (11) \\
\hline \multirow[t]{7}{*}{$\begin{array}{l}\text { dias melhores } \\
\text { virão }\end{array}$} & $\begin{array}{l}\text { eu tenho essa crença que é possível construir algo muito relevante, mesmo com as limitações que nós temos de recursos } \\
\text { e conhecimento (4) }\end{array}$ \\
\hline & Com certeza (...) Tem tudo para dar certo todo (5) \\
\hline & Com certeza (...) Eu sempre vou achando que vai melhorar, porque senão é preferível você desistir (6) \\
\hline & a partir do ano que vem vai ter dias melhores (7) \\
\hline & Sim (...) eu sou otimista por natureza (8) \\
\hline & $\begin{array}{l}\text { eu acho que a gente tem um grupo de alunos e um grupo de professor que tem um grande potencial pra produzir mais, } \\
\text { e não só reproduzir conhecimento, mas produzir conhecimento (10) }\end{array}$ \\
\hline & eu tenho que pensar que tudo vai ser melhor, que tudo vai convergir para uma situação melhor lá na frente (11) \\
\hline \multirow{2}{*}{$\begin{array}{l}\text { ter planos para } \\
\text { meu futuro }\end{array}$} & Sim (...) Espero crescer sempre (6) \\
\hline & Tenho (...) aqui ainda é meu caminho e eu vejo ainda muita perspectiva (8) \\
\hline $\begin{array}{l}\text { amanhã será } \\
\text { melhor }\end{array}$ & $\begin{array}{l}\text { Eu acho que o envolvimento das pessoas vai proporcionar isso, semeando coisas boas agora, com a base do discurso, a } \\
\text { gente vai envolver mais, a gente vai ter mais gente produzindo conhecimento (10) }\end{array}$ \\
\hline
\end{tabular}

Os professores têm a percepção de que tudo dará certo com eles no seu trabalho $(1,2,5$, 6, 7 e 8). Essa percepção se justifica por acreditarem que tudo tem solução (2), que isso se deve a realizar as tarefas de forma bem-feita e com boas intenções (7). Consequentemente, também enxergam que dias melhores virão, isto é, por acreditarem que estão construindo algo relevante como professores (4), do contrário seria preferível desistir (6). Percebe-se que esses indivíduos 
têm essa visão otimista e acreditam que fatores negativos são circunstâncias temporárias (YOUSSEF; LUTHANS, 2007), isso fica claro quando mencionam que é necessário se acalmar e esperar o dia seguinte, pois as coisas melhorarão (2) e também por visualizarem uma situação melhor lá na frente (11) assim que superarem adversidades atuais.

Esses professores também esperam ter planos para sempre crescer (6). Observam, ainda, muitas perspectivas (8). Eles têm a percepção de que o amanhã será melhor (10), o envolvimento das pessoas vai proporcionar isso, semeando coisas boas agora, com a base do discurso, vai-se envolver mais e ter mais pessoas produzindo conhecimento. Esse otimismo move os indivíduos ao sucesso e melhora a saúde física, psicológica e organizacional (LUTHANS, 2002).

Por fim, tem-se a última característica do capital psicológico, a resiliência, se refere à capacidade de se recompor após uma adversidade (LUTHANS; YOUSSEF, 2004). A Tabela 6 apresenta as constatações relacionadas aos questionamentos sobre a capacidade dos professores de se recomporem após enfrentarem diferentes adversidades, como uma demissão, mudanças, perdas, dificuldades, intrigas, inveja etc.

Tabela 6 - Capital Psicológico do Trabalho - Resiliência

\begin{tabular}{|c|c|}
\hline Subcategoria & Entrevistas \\
\hline \multirow{11}{*}{$\begin{array}{l}\text { enfrentar } \\
\text { demissão }\end{array}$} & Me sinto preparada (1) \\
\hline & eu já fui demitido duas vezes de faculdade, para mim é normal, não me abalo (2) \\
\hline & saber que cada dificuldade é uma lição para um novo aprendizado (3) \\
\hline & $\begin{array}{l}\text { nunca tive receio de ser dispensado (...) eu acho que para aqueles que trabalham, que se dedicam, que são comprometidos com } \\
\text { a qualidade, tem campo de trabalho (...) acho que os primeiros anos da docência pra mim foram desafiantes (4) }\end{array}$ \\
\hline & $\begin{array}{l}\text { se eu passasse por uma situação de demissão, é algo que ia me incomodar em um primeiro momento, mas eu ia buscar outras } \\
\text { alternativas (5) }\end{array}$ \\
\hline & A minha situação é precaver para que eu consiga manter o meu padrão de vida, já buscando outras oportunidades (6) \\
\hline & eu não teria tanto impacto, em termos profissionais, porque eu conheço o mercado, tenho alternativas (7) \\
\hline & nunca experimentei uma demissão (...) eu não sei o que fazer (8) \\
\hline & $\begin{array}{l}\text { a questão de se recompor ela se torna fácil, o mercado ele ta de portas abertas pra profissionais qualificados e eu acho que hoje } \\
\text { seria fácil de se realocar no mercado de trabalho (9) }\end{array}$ \\
\hline & $\begin{array}{l}\text { é bola pra frente e pensar no trabalho, pensar no futuro, e deixar o que aconteceu, as vezes uma decisão não é nem uma decisão } \\
\text { errada (10) }\end{array}$ \\
\hline & $\begin{array}{l}\text { pode ser que choca (...) todo negativo tem que ser tirado o positivo, e é desse positivo que se encontra forças pra continuar na } \\
\text { caminhada (11) }\end{array}$ \\
\hline \multirow{4}{*}{$\begin{array}{l}\text { enfrentar } \\
\text { mudanças }\end{array}$} & Para mim mudar não é nenhum problema não (2) \\
\hline & creio que consigo me recompor rapidamente (3) \\
\hline & a gente tem que aprender a lidar com as mudanças e isso faz parte das coisas que surgem (5) \\
\hline & Eu consigo me adaptar de forma tranquila (6) \\
\hline $\begin{array}{l}\text { enfrentar } \\
\text { perdas }\end{array}$ & $\begin{array}{l}\text { eu tenho um pouco de dificuldade no início, até compreender a nova metodologia a ser utilizada eu tenho um pouco de } \\
\text { dificuldade, mas a gente tenta se adaptar de acordo com o que for necessário (9) }\end{array}$ \\
\hline \multirow{5}{*}{$\begin{array}{l}\text { enfrentar } \\
\text { dificuldades }\end{array}$} & Me sinto capaz (1) \\
\hline & precisa se adequar se atualizar constantemente (...) Não é fácil em um primeiro momento, mas depois a coisa acontece (5) \\
\hline & eu me sinto muito forte e consigo resolver as coisas de uma forma tranquila (6) \\
\hline & alguns em menor escala são mais fáceis (7) \\
\hline & refletir em formas de minimizar essa dificuldades, e não deixar isso prejudicar o teu trabalho futuro (10) \\
\hline \multirow{5}{*}{$\begin{array}{l}\text { enfrentar } \\
\text { intrigas }\end{array}$} & tentaria me adequar da melhor forma, não prejudicar os alunos, não prejudicar a instituição (1) \\
\hline & se a gente viu que errou, a gente vai lá e pede desculpas e fica de boa (2) \\
\hline & $\begin{array}{l}\text { não construo nenhuma intriga no meu ambiente, não estimulo levar ou trazer qualquer percepção negativa das pessoas (...) eu } \\
\text { faço tudo que for possível para o ambiente ser mais cooperativo, seja o mais adequado, mais agradável, e mais operacional } \\
\text { possível (4) }\end{array}$ \\
\hline & eu prefiro resolver meus conflitos de forma individual (6) \\
\hline & problemas de relacionamentos pessoais internos aqui, não passei por essa experiência (7) \\
\hline
\end{tabular}




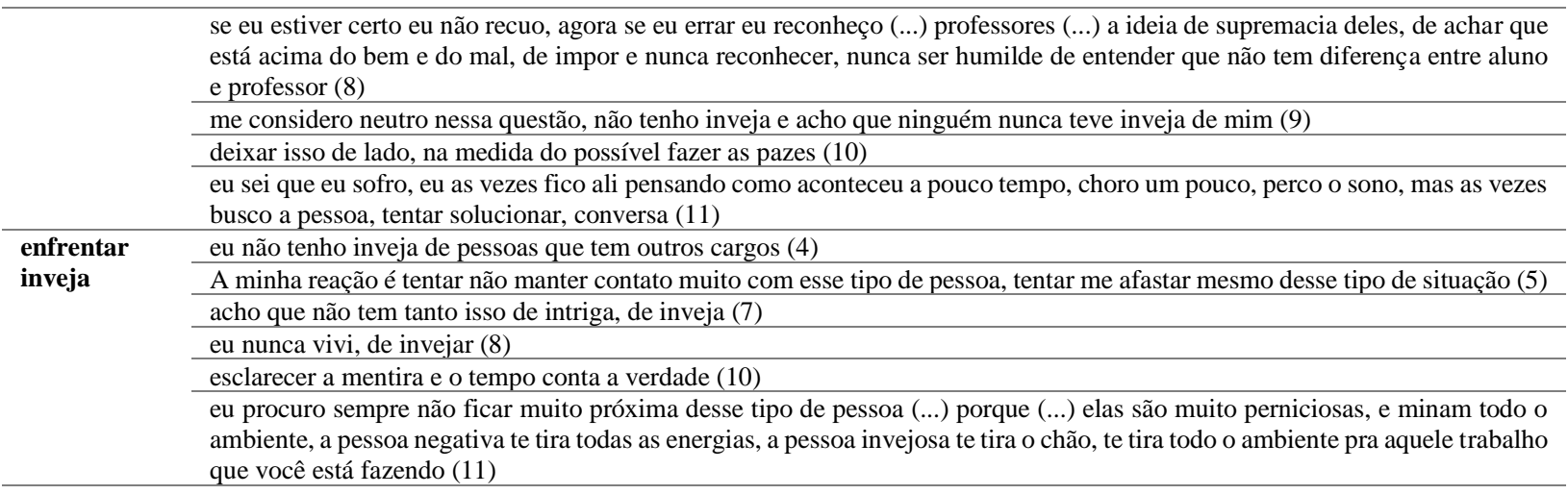

Fonte: Elaborada pelos autores (2017).

Os professores se mostram com boa capacidade de recuperação diante de uma situação como uma demissão. Eles se mostraram preparados $(1,4,6,7$ e 9), evidenciam que cada dificuldade é uma lição para um novo aprendizado (3), essa preocupação também é menor devido às características desses profissionais, isto é, se dedicam e são comprometidos (4), o mercado está aberto para profissionais qualificados (9). Apesar de mostrarem que às vezes até nunca passaram por isso e não saberiam o que fazer (8), acreditam que de todos os aspectos negativos é possível extrair algo positivo (11).

No que refere a mudanças, eles acreditam não ser um problema (1) e também julgam que conseguem se recompor rapidamente (3) e de forma tranquila (6). As mudanças fazem parte de qualquer realidade e, para a atuação docente, não é diferente; é necessário, aprender a lidar com essas mudanças (5). Essa capacidade pode estar relacionada à autoeficácia, visto que a capacidade de recompor parte do pressuposto que o indivíduo também consiga mobilizar recursos cognitivos para obter resultados específicos (LUTHANS; YOUSSEF, 2004).

Perdas e dificuldades também são presentes na realidade do professor universitário de Contabilidade. Alguns se mostram até com dificuldade ao início (5 e 9), mas mostram que é necessário refletir em formas de minimizar essas dificuldades e não deixar que isso prejudique o trabalho (10). Ao mesmo tempo, os professores se sentem capazes (1) e fortes (6) para superar as adversidades. Entende-se, assim como Luthans et al. (2007) mencionam, a dificuldade maior está no início realmente, haja vista que o professor universitário ainda não passou por outras adversidades; superá-las melhorar sua capacidade e o torna mais resiliente.

Outra situação que os professores também enfrentam são intrigas e inveja. Eles mencionam que diante de intrigas tentam se adequar não prejudicando os alunos e/ou a instituição (1), buscam não trazer percepções negativas das pessoas, buscam um ambiente cooperativo (4), evidenciam que é importe deixar isso de lado (10). Entretanto, também existem pessoas mais emocionais que sofrem com isso (11). Quanto a situações de inveja, demonstram 
que isso não é algo tão presente (4, 7 e 8);mencionam também que buscam superar essas adversidades não mantendo contato (5 e 11), esclarecendo a mentira (10).

Portanto, isso mostra que professores universitários de Contabilidade se sentem bem preparados para enfrentar uma situação de demissão, as perdas e as mudanças são piores ao início, mas pela superação e pela experiência se tornam mais fáceis de se recompor, assim como evidenciam Luthans et al., (2007), Demo, Oliveira e Costa (2017). As intrigas e inveja também não prejudicam a atuação docente, segundo os entrevistados; por isso, se mostram mais resilientes para enfrentar essas adversidades.

Percebe-se que as quatro características, autoeficácia, esperança, otimismo e resiliência, parecem ser inerentes à realidade da profissão de professor, sendo, por isso, aplicadas em conjunto, o que justifica as motivações desses indivíduos (YOUSSEF; LUTHANS, 2007), o que contribui para gerar benefícios para a organização em que eles estão presentes (VILAÇA; MÓNICO; CASTRO, 2012). Uma justificativa para esses constructos em conjunto é o fato de que indivíduos que conseguem realizar seus próprios objetivos tendem a ser mais esperançosos, por isso, têmuma melhor visão sobre suas capacidades, uma melhor perspectiva do futuro e também uma melhor adaptação a situações adversas (LUTHANS et al. 2007).

\subsection{Satisfação no Trabalho}

A satisfação no trabalho desempenha um papel importante no alcance de objetivos, no desempenho educacional e na qualidade de ensino (BULUC; GUNES; 2014; SANTOS; BEUREN, 2017). A satisfação no trabalho é um autoavaliação positiva do seu trabalho, de experiências, de circunstância e de práticas (ALSHITRI, 2013).

Alguns estudos já fizeram algumas correlações entre o capital psicológico do trabalho e os seus elementos constituintes (autoeficácia, esperança, resiliência e otimismo) e a satisfação no trabalho (AVEY et al., 2011; LUTHANS et al., 2010; YOUSSEF; LUTHANS, 2007). Este estudo se propõe a entender essas relações e analisar como se constitui o capital psicológico e a satisfação no trabalho de professores universitários de Contabilidade.

Buscando verificar a percepção do indivíduo sobre a avaliação que ele faz do seu trabalho, tem-se a Tabela 7, a qual evidencia as constatações realizadas a respeito da satisfação que os professores universitários têm em relação: ao espírito de colaboração dos seus colegas, ao salário comparado com o quanto ele trabalha, ao grau de interesse que as tarefas têm despertado, ao salário comparado à capacidade profissional, a fazer o tipo de trabalho que faz, e, por fim, ao entendimento entre ele e seu chefe. 


\begin{tabular}{|c|c|}
\hline \multirow{7}{*}{$\begin{array}{l}\text { espírito de } \\
\text { colaboração dos } \\
\text { colegas }\end{array}$} & $\begin{array}{l}\text { Sim (...) o ambiente de trabalho é muito bom (...) os colegas são muito comprometidos como curso e isso torna um } \\
\text { ambiente bom (4) }\end{array}$ \\
\hline & Sim (...) os colegas são bem bacanas (5) \\
\hline & Sim (...) eu percebo uma colaboração da maioria, não de todas, mas a maioria colabora muito entre si (6) \\
\hline & $\begin{array}{l}\text { eu tenho que relativizar (...) não posso dizer assim que no grupo que a gente está, no nosso colegiado, que } 100 \% \\
\text { pensa dessa forma, de ter amizade, colaboração, e comprometimento, porque tem questões divergentes }(8)\end{array}$ \\
\hline & altamente satisfeito com a colaboração que nós temos perante o grupo de docentes da instituição. (9) \\
\hline & acho que são muito colaborativos, parceiros eu me sinto satisfeito com isso (10) \\
\hline & Sim (...) são muito parceiros (11) \\
\hline \multirow{11}{*}{$\begin{array}{l}\text { Salário } \\
\text { comparado com } \\
\text { o quanto eu } \\
\text { trabalho }\end{array}$} & $\begin{array}{l}\text { é uma das instituições que melhor remunera (...) embora receba hora-atividade, eu acho que não é suficiente, está } \\
\text { longe de ser suficiente algum dia pelo tanto que a gente trabalha. (1) }\end{array}$ \\
\hline & $\begin{array}{l}\text { O problema está no contexto mesmo que o professor é mal remunerado mesmo, não só no privado, é no geral mesmo } \\
\text { que o professor é mal remunerado (2) }\end{array}$ \\
\hline & não vou dizer muito satisfeito (3) \\
\hline & $\begin{array}{l}\text { considero o salário maior do que o da grande maioria da população (...) estou satisfeito com o meu salário (...) meu } \\
\text { salário sempre sobrou, quando eu ganhava um salário mínimo sobrava, agora eu ganho bem mais e sobra, e eu faço } \\
\text { a mesma gestão (4) }\end{array}$ \\
\hline & Sim (...) eu acredito que a instituição ela é bem justa nesse aspecto, está coerente com a função (5) \\
\hline & $\begin{array}{l}\text { Não (...) como professor a questão salarial não é uma consequência do seu trabalho, a consequência do seu trabalho } \\
\text { é satisfação pessoal (...)financeiramente eu não me sinto satisfeita (6) }\end{array}$ \\
\hline & é uma satisfação parcial, não é ruim, não é de jogar fora, mas não é de dar uma satisfação 100\% (7) \\
\hline & $\begin{array}{l}\text { Não (...) não que eu não esteja satisfeito (...) as responsabilidades que eu tenho que eu exerço no momento, e a carga } \\
\text { que eu tenho, eu fazer uma relação com o meu ganho é desproporcional (8) }\end{array}$ \\
\hline & a remuneração financeira não é tão satisfatória (9) \\
\hline & eu acho que $\operatorname{sim}(10)$ \\
\hline & não me considero insatisfeita (11) \\
\hline \multirow{4}{*}{$\begin{array}{l}\text { grau de interesse } \\
\text { que as tarefas } \\
\text { despertam }\end{array}$} & Sim (...) a docência é algo que eu gosto, inspira muitos desafios (3) \\
\hline & Sim (...) as atividades surgidas na graduação e no mestrado me motivam, desafiam (4) \\
\hline & Com certeza (...) eu tenho o maior prazer de estar em sala de aula, de estar pesquisando (7) \\
\hline & $\begin{array}{l}\text { To (...)você vai ser pago pra estudar, isso que motivava e continua motivando, virou uma missão ao invés de ser só } \\
\text { uma atividade (8) }\end{array}$ \\
\hline \multirow{3}{*}{$\begin{array}{l}\text { salário } \\
\text { comparado à } \\
\text { minha } \\
\text { capacidade } \\
\text { profissional }\end{array}$} & teria que ter uma melhor remuneração (1) \\
\hline & a educação não vale o tempo intelectual que é dispendido (6) \\
\hline & não considero o salário satisfatório com relação a minha capacidade (9) \\
\hline \multirow{6}{*}{$\begin{array}{l}\text { fazer o tipo de } \\
\text { trabalho que faz }\end{array}$} & Considero muito satisfeita com o trabalho que eu faço (1) \\
\hline & $\begin{array}{l}\text { Com certeza (...) a profissão docente ela é muito especial no sentido que a gente realmente contribui de alguma forma } \\
\text { para a sociedade (5) }\end{array}$ \\
\hline & $\begin{array}{l}\text { Com certeza (...) As oportunidades que estão surgindo, as disciplinas que me oferecem, esses desafios são sempre } \\
\text { satisfatórios (6) }\end{array}$ \\
\hline & $\begin{array}{l}\text { To (...) satisfação de pegar um conteúdo, preparar esse conteúdo, levar pra sala de aula, fomentar a discussão, da } \\
\text { discussão você propor caminhos ou receber proposição de caminhos de pesquisa, de caminho de discussão e você ir } \\
\text { agregando isso (8) }\end{array}$ \\
\hline & Sim, me sinto satisfeito com essa oportunidade (10) \\
\hline & $\begin{array}{l}\text { Sim, eu me sinto feliz (...) isso tava na minha alma a questão da docência (...)me proporciona ganhos (...) o ganho } \\
\text { intelectual, o ganho profissional, o ganho como pessoa (11) }\end{array}$ \\
\hline \multirow{3}{*}{$\begin{array}{l}\text { entendimento } \\
\text { com seu chefe }\end{array}$} & Sim (...) sempre tive muita facilidade e muito acesso a esses dirigentes (8) \\
\hline & $\begin{array}{l}\text { Me considero, porque acho que todos os meus superiores (...) são pessoas muito colaborativas, pessoas do bem, que } \\
\text { também pensam nesse crescimento de todo o grupo de toda a universidade, do centro, do curso (10) }\end{array}$ \\
\hline & $\begin{array}{l}\text { Com certeza (...) os superiores que eu tenho, nessa hierarquia, são muito importantes, pessoas muito coerentes, } \\
\text { equilibradas, e que realmente me instigam a continuar nessa caminhada (11) }\end{array}$ \\
\hline
\end{tabular}

Fonte: Elaborada pelos autores (2017).

Os professores demonstram-se satisfeitos com o espírito de colaboração de seus colegas $(4,5,6,9,10$ e 11), isso se deve ao ambiente de trabalho (4), à colaboração e à parceria de colegas $(5,6,9,10$ e 11). Ainda que essa satisfação não seja com todos (8), percebe-se que eles se mostram bem satisfeitos. Também entendem que a relação entre os seus respectivos chefes é satisfatória (10, e 11); eles os veem como pessoas colaborativas, pensam no crescimento como um tudo (10) e instigam a continuar na profissão de professor (11). Essa satisfação que eles percebem com as pessoas a sua volta ressalta a característica de confiança (autoeficácia) e resiliência que eles têm em superar os seus desafios, alcançando bons resultados ainda que diante de ameaças e mudanças (MASTEN, 2001). 
A satisfação de professores universitários de Contabilidade no que se refere aos seus salários comparada ao quanto eles trabalham não é geral, visto que alguns se mostraram satisfeitos $(4,5$ e 10) e outros não $(1,2,3,6,7,8$ e 9). As razões que justificam a satisfação dos professores se dão pelo fato de eles acreditarem que o seu salário é maior que o da maioria da população (4) e, por isso, seria coerente com a função (5). De outra forma, comparando-se à satisfação com a capacidade profissional, também não visualizam como satisfatório (1 e 6), consideram que deveria haver uma melhor remuneração (1), visto que o que é pago não vale o tempo intelectual dispendido (6). A insatisfação ou não satisfação com o salário que recebem podem gerar um descontentamento, o que pode prejudicar o capital psicológico desses indivíduos (LUTHANS, 2002), ou até mesmo o seu comprometimento com a organização (BULUC; GUNES; 2014).

A atuação docente é gratificante, por isso, os entrevistados se mostram satisfeitos com o grau de interesse que as tarefas têm despertado. Os motivos da satisfação são: inspirar desafios (3), a motivação e os desafios que ela proporciona (4) e o prazer por continuar estudando e encarar isso como uma missão (8). Da mesma forma, esses professores consideram satisfeitos de ter a oportunidade de fazer o tipo de que trabalho que fazem $(1,5,6,8,10$ e 11).

Eles acreditam que a atuação docente é especial e contribui de alguma forma para a sociedade (5), os desafios são satisfatórios (6) e proporcionam ganho intelectual, profissional e pessoal (11). Essa constatação pode justificar a característica de otimismo, em que o indivíduo busca explicar eventos positivos por meio de uma visão interna do ser, de forma permanente, relacionando fatores negativos a circunstâncias e a fatores temporários (YOUSSEF; LUTHANS, 2007).

Percebe-se que esses indivíduos estão satisfeitos com o espírito de colaboração de colegas, com o grau de interesse que as tarefas despertam, da oportunidade de fazer esse tipo de trabalho e do entendimento com os seus chefes. Esse ambiente demonstra que os indivíduos estão felizes com o seu trabalho (SANTOS; BEUREN, 2017) e têm o prazer profissional de exercer essa atividade (ALTAHAYNEH; KHASAWNEH; ABEDALHAFIZ, 2014).

Essa satisfação profissional favorece o clima organizacional, o que possibilita a valorização de seus objetivos e realização de suas metas (ANDRADE, BARBOSA, SOUZA \& MOREIRA, 2015). Essa constatação pode justificar o porquê da esperança que os professores universitários têm em realizar seus próprios objetivos (YOUSSEF; LUTHANS, 2007).

\subsection{Comprometimento Organizacional}


O último constructo da análise se trata do comprometimento dos professores universitários de Contabilidade com as suas instituições. O comprometimento está associado à identificação do colaborador com a organização e com os seus respectivos objetivos (MOWDAY; STEERS; PORTER, 1979). O comprometimento se subdivide em comprometimento afetivo, comprometimento normativo e comprometimento calculativo.

O comprometimento afetivo é quando o indivíduo se sente emocionalmente ligado e envolvido com a organização (MEYERS; ALLEN, 1991). Assim, buscou-se avaliar como se constitui esse tipo de comprometimento com professores universitários. A Tabela 8 demonstra as constatações obtidas com as entrevistas no que se refere aos respectivos sentimentos que eles têm com a instituição sobre os seguintes atributos: confiança, gostar, empolgação, fidelidade, apego, orgulho, contente, responsável, dedicado e envolvido.

\section{Tabela 8 - Comprometimento Organizacional Afetivo}

\begin{tabular}{|c|c|}
\hline Subcategoria & Entrevistas \\
\hline \multirow[t]{10}{*}{ Confiante } & Hoje me sinto confiante, me sinto segura (1) \\
\hline & $\begin{array}{l}\text { A universidade tem uma estrutura muito boa, e procura sempre estar atualizando os seus quadros, sempre fazendo } \\
\text { palestras, e isso é muito bom (2) }\end{array}$ \\
\hline & $\begin{array}{l}\text { me sinto confiante (...) porque a instituição ela proporciona, essa segurança, essa confiança em nós professores, essa } \\
\text { valorização profissional também, pelo próprio nome da instituição (3) }\end{array}$ \\
\hline & $\begin{array}{l}\text { eu não tenho confiança na instituição (...) A instituição é muito distante, eu não sei o que estão pensando (...) as coisas } \\
\text { não são muito claras, há muitas posturas que eu discordo do reitor, discordo também de alguns departamentos que ferem } \\
\text { os meus princípios, os meus valores (...) por outro lado eu acho que (...) há uma proximidade muito rica entre os colegas } \\
\text { (4) }\end{array}$ \\
\hline & Sim (...) tem essa confiança no ambiente, nos alunos (5) \\
\hline & Eu tenho uma confiança neles da mesma forma que eu acho que eles têm uma confiança no meu trabalho também. (6) \\
\hline & confiante no sentido de que a universidade está cumprindo a sua obrigação, a sua função (7) \\
\hline & $\begin{array}{l}\text { Sim (...) mesmo nos momentos de crise, de conflito, eu sempre tenho uma confiança na instituição e nas normas que você } \\
\text { vai solucionar e vai resolver (8) }\end{array}$ \\
\hline & $\begin{array}{l}\text { me sinto confiante pela forma de atuação que a gente trabalha e pela forma que a gente recebe as avaliações que é feita } \\
\text { semestral e as vezes mensal na instituição (9) }\end{array}$ \\
\hline & do centro pra baixo sim, da reitoria não (10) \\
\hline \multirow[t]{6}{*}{ Gostar } & $\begin{array}{l}\text { é uma instituição que oferece boas condições de trabalho, tem uma boa estrutura de se trabalhar, os alunos têm um perfil } \\
\text { de muito respeito com os professores (1) }\end{array}$ \\
\hline & Sim (...) eu já deixei de dar aula em outra instituição para ficar só nessa universidade (2) \\
\hline & Eu gosto da instituição, eu acho o ambiente da universidade muito bom (4) \\
\hline & Eu gosto muito de trabalhar nesta instituição (6) \\
\hline & Gosto (...) Pela forma que ela trabalha com os docentes (...) família (9) \\
\hline & $\begin{array}{l}\text { Sim, gosto, pelo ambiente de trabalho, pela produção, pelos alunos, é um conjunto de valores institucionais que eu prezo, } \\
\text { que eu me identifico com isso (10) }\end{array}$ \\
\hline \multirow[t]{7}{*}{ Empolgado } & Me sinto empolgada (1) \\
\hline & Não me sinto empolgado (2) \\
\hline & Eu acho que alguns projetos geram empolgação, mas de forma geral, no cotidiano, não (4) \\
\hline & $\begin{array}{l}\text { Sim (...) A cada conteúdo que eu vou lecionar eu me empolgo com ele (...) eu sou empolgada com as minhas turmas e as } \\
\text { disciplinas que eu leciono (6) }\end{array}$ \\
\hline & Sim (...) eu me empolguei como professor (7) \\
\hline & me sinto empolado, pelo sentido de ela dar apoio e mostrar interesse pelo professor, no sentido profissional (9) \\
\hline & me sinto empolgada, animada, me sinto viva estando aqui dentro (11) \\
\hline \multirow[t]{9}{*}{ Fiel } & me sinto fiel a instituição (1) \\
\hline & $\begin{array}{l}\text { Sim (...) se aparecesse outra oportunidade para trabalhar em outro lugar eu iria de boa (...) Minha fidelidade estar lá se } \\
\text { justifica pela oportunidade que eles me deram quando eu cheguei aqui (2) }\end{array}$ \\
\hline & Me considero fiel, sim, dedicado, comprometido com a instituição (4) \\
\hline & sou bem fiel, bem comprometida com o trabalho (5) \\
\hline & Eu sou fiel, sim, em termos de relacionamento, em questões éticas com a universidade (6) \\
\hline & eu sou fiel, a coordenação, aos alunos, a relação entre professor e alunos, e a própria instituição (7) \\
\hline & Sim, me considero bastante fiel (8) \\
\hline & $\begin{array}{l}\text { Me considero (...) todo o trabalho que eu tenho, basicamente tá envolvido só a universidade, é produção de artigo, é } \\
\text { preparação de aula, é a valorização, ajudar o pessoal nos eventos que envolvam a universidade, a divulgação da } \\
\text { universidade (10) }\end{array}$ \\
\hline & Sim, me considero, porque cada vez mais eu me sinto não apenas com a obrigação (11) \\
\hline
\end{tabular}




\begin{tabular}{|c|c|}
\hline \multirow[t]{4}{*}{ Apegado } & eu já sinto um apego pela instituição pessoal (1) \\
\hline & Existem, sim, uma relação de apego, porque vai muito além do salário (4) \\
\hline & $\begin{array}{l}\text { talvez um apego emocional, não sei, porque foi a primeira instituição que me deu essa oportunidade, então eu valorizo } \\
\text { isso (5) }\end{array}$ \\
\hline & com certeza (11) \\
\hline \multirow[t]{6}{*}{ Orgulhoso } & por ser uma boa instituição tenho orgulho de fazer parte dela (1) \\
\hline & Tenho orgulho de fazer parte dessa equipe, tenho orgulho pela oportunidade que tenho de participar desse processo (4) \\
\hline & tenho orgulho da instituição (5) \\
\hline & $\begin{array}{l}\text { é uma oportunidade ímpar que você tem, e você entra e você vai amadurecendo, e eu me sinto sim orgulhoso por ser } \\
\text { professor e poder contribuir de certa forma com a sociedade (7) }\end{array}$ \\
\hline & Sim, orgulho pela construção (...) porque essa universidade foi construída com muita luta (8) \\
\hline & $\begin{array}{l}\text { eu me considero orgulhoso, porque como eu já me formei naquela instituição isso já me da um orgulho, sobre trabalhar } \\
\text { nela também (9) }\end{array}$ \\
\hline \multirow[t]{2}{*}{ Contente } & Há um descontentamento (...) Não chega, talvez, um descontentamento, mas um incômodo (4) \\
\hline & me sinto contente (5) \\
\hline \multirow[t]{7}{*}{ Responsável } & $\begin{array}{l}\text { Qualquer atitude que se faça, que vá, digamos, tirar o prestígio da instituição, tirar o status, é uma carga muito grande de } \\
\text { responsabilidade. Eu me sinto responsável, sim (1) }\end{array}$ \\
\hline & Me sinto responsável (...) pelo o que está construído atualmente (4) \\
\hline & Me sinto responsável pelos alunos, diretamente (5) \\
\hline & Eu me sinto responsável (6) \\
\hline & eu sou responsável (7) \\
\hline & $\begin{array}{l}\text { me sinto responsável (...) quem me trouxe aqui me deu uma missão, e eu me sinto realizado porque eu tenho conseguido } \\
\text { cumprir essa missão (8) }\end{array}$ \\
\hline & me sinto responsável (9) \\
\hline \multirow[t]{2}{*}{ Dedicado } & me dedico muito para as atividades (1) \\
\hline & eu não quero entristecer, eu não quero decepcionar (3) \\
\hline \multirow[t]{3}{*}{ Envolvido } & me sinto muito envolvida (1) \\
\hline & $\begin{array}{l}\text { Envolvido sim, ela envolve basicamente os professores dentro do seu contexto, já que ela trabalha de uma forma mais } \\
\text { familiar (9) }\end{array}$ \\
\hline & me sinto envolvido mas poderia ser mais $(\ldots)$ poderia ter mais comunicação $(\ldots)$ continuar nos grupos de pesquisa $(10)$ \\
\hline
\end{tabular}

Fonte: Elaborada pelos autores (2017).

Percebe-se que existe uma relação de confiança com a universidade que esses professores atuam $(1,3,5,6,7,8$ e 9), isso devido a se sentirem seguros dentro da instituição (1), além de proporcionar valorização profissional a esses profissionais (3). Também existe um certo grau de desconfiança (4 e 10), visto que a instituição se torna muito distante, as coisas não são muito claras $(4,10)$, principalmente no que se refere à reitoria e a outros departamentos relacionados.

Observa-se que esses professores também gostam de trabalhar nessas instituições $(1,2$, 4, 6, 9 e 10). A instituição oferece boas condições de trabalho, tem uma boa estrutura, os alunos têm uma postura de respeito com os professores (1), até mesmo o próprio ambiente de trabalho, a produção acadêmica e o conjunto de valores institucionais são fatores que fazer com que os professores gostem de trabalhar na instituição.

Os docentes também se sentem empolgados por trabalhar nessa instituição $(1,6,7,9$ e 11), enquanto outros não veem isso da mesma forma (2 e 4). Essa empolgação é obtida quando se vai lecionar uma aula, com as próprias turmas e as disciplinas (6) e também pelo fato de que a instituição também apoia e mostra interesse por esse profissional (9).

Todos professores também se mostraram fiéis às suas instituições (1, 2, 4, 5, 6, 7, 8 e 10), isso porque entendem a oportunidade que receberam em trabalhar naquele lugar (2). $\mathrm{O}$ envolvimento que se tem com a universidade, seja para a produção de artigos, preparação de aulas, ajudar na preparação de eventos e na divulgação da própria universidade, fortalece essa característica de fidelidade com a instituição. 
Consequentemente, também existe uma relação de apego com a instituição (1, 4, 5 e 11), que vai muito além do salário (4); se trata de um apego emocional (5). Isso também gera orgulho por parte dos professores com a instituição $(1,4,5,7,8,9)$. Esse sentimento de orgulho se justifica pelo fato de eles acreditarem terem obtido a oportunidade de participar do processo de construção da universidade (4), por contribuir com a sociedade (7) e também por até terem se formado dentro daquela instituição (9).

Existe um descontentamento (4) e um contentamento (9). O descontentamento é devido à distância que se percebe entre os professores e os objetivos institucionais (4); não existe uma transparência suficiente que permita os professores acreditarem nos reais objetivos da instituição.

Os professores também se sentem responsáveis pela instituição (1, 4, 5, 6, 7, 8 e 9). A sensação de responsabilidade é pelo fato de que qualquer atitude que esse empregado faça pode afetar a imagem, o prestígio e o status da instituição (1). Por isso, também percebe-se que existe dedicação por parte desses profissionais (1 e 3), visto que eles não querem decepcionar quem já confiou a eles uma oportunidade. Os professores se sentem envolvidos com a instituição (1, 9 e 10), isso se dá pela forma de trabalhar da instituição, isto é, ser mais familiar (9), a comunicação e os grupos de pesquisa também permitem um melhor envolvimento dentro dessas entidades (10).

Portanto, observa-se que os professores se mostram confiantes com a instituição, gostam, se sentem empolgados, fiéis, apegados, orgulhosos, contentes, responsáveis, dedicados e envolvidos. Demonstram elevado grau de comprometimento afetivo. Esse comprometimento pode estar relacionado às características de esperança e de resiliência (YOUSSEF; LUTHANS, 2007), visto que o fato de eles acreditarem e pensar em objetivos e suas diferentes formas de alcançar esses objetivos (LUTHANS et al., 2007) pode melhorar o comprometimento que eles têm com a instituição. Da mesma forma, sua capacidade de alcançar bons resultados frente a adversidades que exigem que eles se adaptem (MASTEN, 2001) pode influenciar o comprometimento afetivo com a instituição.

A satisfação no trabalho pode estar relacionada ao comprometimento afetivo desses professores, assim como foi observado por Santos e Beuren (2017). Isso se dá quando os docentes apresentam um estado emocional agradável com seu trabalho e das atividades desempenhadas (LOCKE, 1969), desse modo, vivenciam concomitantemente um estado psicológico e sentem um desejo de permanecer na instituição (MEYER; ALLEN; SMITH, 1993; REGO, 2002). 
O comprometimento calculativo está relacionado à percepção que o empregado tem em se manter ligado à instituição, visto que ele reconhece os custos associados com a sua saída (MEYER; ALLEN, 1991; REGO, 2002). Tendo isso em vista, nas entrevistas realizadas, buscou-se analisar como se constitui esse tipo de comprometimento.

Para tanto, colocou-se a situação de um caso em que o professor pede demissão. A partir dessa situação hipotética, observou-se os seguintes atributos: se eles teriam dificuldades de ganhar um salário tão bom quanto o têm hoje, se os esforços estariam sendo jogados fora, se perderiam a estabilidade que tem no emprego hoje, se demorariam a desenvolver relacionamentos com colegas, se perderiam a liberdade que tem hoje no emprego, se acreditavam que seria um desperdício de tempo dispendido na instituição que eles haviam formado vínculo, se estariam deixando para trás tudo que foi investido naquela instituição, se iria prejudicar sua vida profissional, se teriam mais a ganhar ou a perder e, por fim, se eles demorariam a se acostumar com um novo emprego. Algumas das constatações estão evidenciadas na Tabela 9 a seguir.

Tabela 9 - Comprometimento Organizacional Calculativo

\begin{tabular}{|c|c|}
\hline Subcategorias & Entrevistas \\
\hline \multirow[t]{5}{*}{ Salário } & eu acho que teria dificuldades de estar conseguindo me encaixar em um emprego público (1) \\
\hline & Eu não teria problema algum em conseguir uma outra colocação (6) \\
\hline & Não (...) eu vejo até no setor privado muito espaço, pela minha experiência, pela minha titulação (8) \\
\hline & acho que dificuldade de ganhar o mesmo salário não teria. (9) \\
\hline & $\begin{array}{l}\text { Eu acho que não, porque todos estão mais ou menos, universidade federal e estadual estão todas com o mesmo } \\
\text { patamar de salários (10) }\end{array}$ \\
\hline \multirow[t]{11}{*}{ Esforços } & $\begin{array}{l}\text { Eu acho que na profissão docência a gente nunca joga fora nada (...) tudo vai agregando conhecimento, tudo vai } \\
\text { agregando experiência para a gente atuar em um outro lugar se porventura houver essa demissão (1) }\end{array}$ \\
\hline & Não (...) nunca está jogando fora, sempre está agregando (2) \\
\hline & $\begin{array}{l}\text { Sim (...) se eu quisesse abrir mão dessa docência, eu acho que estaria jogando fora, seria algo que teria sido em vão } \\
\text { (3) }\end{array}$ \\
\hline & $\begin{array}{l}\text { Não (...) o que foi construído está mais relacionado a pessoas, a vínculos (...)tudo o que eu construí foi quem mais } \\
\text { levou desse processo de construção, fui eu (4) }\end{array}$ \\
\hline & $\begin{array}{l}\text { Não (...)o esforço a dedicação contribuiu para o meu desenvolvimento, o meu crescimento intelectual, a minha } \\
\text { experiência, eu levo isso para outra instituição que eu for (5) }\end{array}$ \\
\hline & Não (...) Jamais eu pediria demissão sem ter uma outra oportunidade que daria para mim uma satisfação maior (6) \\
\hline & $\begin{array}{l}\text { a partir do momento que eu decidir vou, eu tenho todo um empenho, o meu foco é isso, todo meu foco meu esforço, } \\
\text { meu tempo é isso hoje (7) }\end{array}$ \\
\hline & É isso que me segura aqui, essa teimosia (...) egoísmo (8) \\
\hline & $\begin{array}{l}\text { Se eu pedisse demissão eu não estaria jogando fora, porque tudo que a gente aprendeu, tudo que a gente fez agrega } \\
\text { conteúdo na sua bagagem profissional (9) }\end{array}$ \\
\hline & $\begin{array}{l}\text { Acho que sim, você o nome na região, na universidade onde você está, por mais que você faça uma reputação e } \\
\text { carregue essa reputação, até você começar a produzir na região, você perde um pouquinho (10) }\end{array}$ \\
\hline & Não, porque os esforços são meus, eles fazem parte da minha pessoa (11) \\
\hline \multirow[t]{2}{*}{ Estabilidade } & Se eu saísse hoje da universidade, com certeza, no ano que vem eu estaria em outra universidade (2) \\
\hline & Não (...) pela experiência que eu vivi, como eu fui testado (8) \\
\hline \multirow[t]{5}{*}{$\begin{array}{l}\text { Relacionamentos } \\
\text { com colegas }\end{array}$} & $\begin{array}{l}\text { Acredito que não, acredito que se manter a boa ordem, bom costume, o respeito, profissionalismo, acredito que em } \\
\text { qualquer ambiente de trabalho que você se inserir (7) }\end{array}$ \\
\hline & Não (...) buscando agregar e construir uma coisa que eu construí pelo bem comum (8) \\
\hline & $\begin{array}{l}\text { Não (...) a gente já tem uma política social bem formada, acho que a gente se adapta facilmente perante os futuros } \\
\text { novos colegas (9) }\end{array}$ \\
\hline & $\begin{array}{l}\text { eu acho que sim, a gente demora pra construir isso, os de amizade são mais demorados, os de trabalho quem sabe } \\
\text { não, mas os de amizade seriam mais demorados (10) }\end{array}$ \\
\hline & Não, eu no relacionamento profissional assim não (11) \\
\hline \multirow[t]{2}{*}{ Liberdade } & Não (...) eu consigo me adaptar a questão de normas e regras com facilidade (6) \\
\hline & $\begin{array}{l}\text { Talvez sim, porque talvez indo pra uma outra universidade, não sei se eles me aceitariam tão bem quanto eu fui aceito } \\
\text { aqui (10) }\end{array}$ \\
\hline
\end{tabular}




\begin{tabular}{|c|c|}
\hline & $\begin{array}{l}\text { De uma certa forma sim, porque são posicionamentos diferenciados que se tem, uma instituição pública tem uma } \\
\text { forma de observar a caminhada do docente né, fazer com que aja essa dinâmica dentro do corpo docente, já uma } \\
\text { instituição privada, como eu já passei por ela, é diferente também, eles têm formas diferentes de observar (11) }\end{array}$ \\
\hline \multirow{3}{*}{$\begin{array}{l}\text { Desperdício de } \\
\text { Tempo }\end{array}$} & Sim (...) é o que me segurou em muitos momentos (8) \\
\hline & $\begin{array}{l}\text { Não, não estaria desperdiçando, porque a gente aproveita essa bagagem cultural que a gente teve perante esses últimos } \\
\text { quatro anos de estudo na instituição (9) }\end{array}$ \\
\hline & $\begin{array}{l}\text { Eu acho que não, acho que a gente constrói uma reputação, é um trabalho que para e a gente espera que outra pessoa } \\
\text { continue (10) }\end{array}$ \\
\hline \multirow[t]{2}{*}{ Investimento } & não é jogado fora (...) agrega pessoalmente e profissionalmente (1) \\
\hline & $\begin{array}{l}\text { eu acho que deixa sim, porque é um grupo de pesquisa que você desenvolve por aqui, com questões locais, com os } \\
\text { alunos daqui (10) }\end{array}$ \\
\hline \multirow[t]{7}{*}{ Vida profissional } & eu teria que ponderar as vantagens e desvantagens da situação (5) \\
\hline & eu acredito que se caso eu pedisse demissão, ou fosse demitida, não iria fazer com que eu estacionasse na vida (6) \\
\hline & Sim (...) todo um foco, pra essa carreira, se você faz esse desvio, você tem um prejuízo (7) \\
\hline & Não (...) eu teria espaço tranquilamente em outros lugares (8) \\
\hline & não estaria prejudicando, nem como profissional nem como docente também não (9) \\
\hline & eu acho que não, profissional não, porque a gente continua o trabalho em outro local (10) \\
\hline & Não (...) seriam novos desafios, teria que me adaptar à realidade deles (11) \\
\hline \multirow[t]{8}{*}{ Ganhar/perder } & Eu acredito que mais coisas a ganhar, por estar buscando novos desafios, novos horizontes (1) \\
\hline & $\begin{array}{l}\text { se eu pedisse demissão hoje, em um contexto de crise econômica, no contexto de dificuldades de contratação, em um } \\
\text { curto prazo, eu teria mais a perder (4) }\end{array}$ \\
\hline & Eu acho que novas experiências sempre é positivo (5) \\
\hline & se eu pedisse demissão é porque eu vejo que tem coisa melhor pela frente (6) \\
\hline & isso é relativo, vai da situação (7) \\
\hline & Depende (9) \\
\hline & $\begin{array}{l}\text { eu acho que mais a perder de um modo geral, por causa que quando você está a mais tempo no local, você está mais } \\
\text { entrosado com a sua parte comportamental, você conhece melhor e consegue extrais o melhor daquele conjunto de } \\
\text { fatores (10) }\end{array}$ \\
\hline & não seria algo tão positivo não (11) \\
\hline \multirow[t]{4}{*}{ Acostumar } & eu acho que acostumaria em um novo trabalho com facilidade (1) \\
\hline & eu acho que eu não teria as dificuldades que eu tive no início (7) \\
\hline & $\begin{array}{l}\text { Sim (...)é outra cultura, você cria certos laços e certo vícios que as pessoas aturam e aceitam, e pra você ir pra outro } \\
\text { ambiente essa é parte mais difícil (8) }\end{array}$ \\
\hline & $\begin{array}{l}\text { Não (...) tudo depende da pessoa, de com que objetivo você está indo ali, você quer formar um grupo, que tipo de } \\
\text { conhecimento você quer a partir disto, o que você está disposto a dar pra esta nova instituição (11) }\end{array}$ \\
\hline
\end{tabular}

Questionados sobre a possibilidade de ganhar um salário tão bom quanto o têm hoje em uma outra instituição caso pedissem demissão, observou-se que os professores não teriam essa dificuldade (6, 8, 9 e 10), visto que a experiência obtida e a titulação que têm (8) não prejudicaria ganhar um salário semelhante em outro lugar. Outra evidência é de que as universidades assemelham-se nos valores pagos como retribuição salarial (10).

Os professores demonstram que também não observam que os esforços estariam sendo jogados fora $(1,2,4,5,6,9$ e 11), ainda que alguns enxergam de outra forma (3, 8 e 10). Percebe-se que não seria um esforço jogado fora, já que todo esses esforços, na verdade, vão agregando conhecimento, experiência, intelectualmente, profissionalmente e pessoalmente (1, $2,4,5,9$ e 11$)$.

A titulação e a experiência que esses professores detêm também proporciona estabilidade; ainda que eles decidam mudar de instituição, a estabilidade não seria se modificaria de forma significativa (8). A liberdade já é vista de outra forma. Acreditam que ir para uma outra instituição prejudica a liberdade que eles têm para realizar o seu trabalho (10 e 11), porque talvez não haveria a mesma aceitação (10), além de se perceber que, ao irem para uma outra 
entidade, encontrariam outros posicionamentos, considerando que universidade públicas e privadas são realidades distintas (11). Outros não se observam prejudicando a sua liberdade (6).

Também não haveria dificuldade de desenvolver relacionamentos com os seus colegas (7, 8, 9 e 11), mantendo-se a boa ordem, o bom costume, o respeito e profissionalismo, isso não se torna uma tarefa difícil (7). Apesar disso, também é mencionado que demoraria para construir os mesmos vínculos de amizade novamente (11).

Os professores apontam que não seria um desperdício de tempo dispendido nesta instituição (9 e 10), outros entendem que sim (8). Entendem que não seria um desperdício porque se aproveita a bagagem cultural (9), acreditam que se constrói uma reputação e que outra pessoa vai continuar o seu trabalho (10). Da mesma forma, entendem que não seria um investimento perdido (1), pois isso agregaria uma bagagem tanto pessoalmente como profissionalmente. Não obstante, também se entende que isso poderia prejudicar o que foi investido (10), como grupos de pesquisa, questões locais e relacionamento com os alunos.

Ademais, não observam essa mudança como algo que prejudicaria sua vida profissional $(6,8,9,10$ e 11$)$, porque acreditam que seriam novos desafios e teriam que estar preparados para se adaptar a eles (11). Porém, consideram essa mudança para outra instituição como um desvio (7).

Questionados se teriam mais a ganhar ou a perder, os respondentes se mostraram bastante confusos, visto que é uma alternativa que depende (7 e 9), vai do contexto e da situação. Os docentes acreditam que teriam também a ganhar (1, 5 e 6), já que estariam buscando novos desafios e novos horizontes (1), valorizam as experiências que isso poderia agregar (5). Todavia, consideram que também poderia ser algo negativo $(4,10$ e 11), haja vista o contexto de crise econômica (4) e também por causa de questões comportamentais e relacionamento com colegas (10).

Os entrevistados demonstram que não teriam dificuldades para se acostumar a um novo ambiente (1, 7 e 11), outros entendem que sim (8). Para eles, isso seria algo que depende da pessoa, de quais são os seus objetivos para mudar de instituição (11), pode ser que seja algo mais difícil ao início de carreira (7).

Portanto, percebe-se que não são os custos de sair dessa instituição que mantêm esses professores ligados a ela (MEYER; ALLEN, 1991; REGO, 2002). Os professores consideram que não teriam dificuldades de ganhar um salário tão bom quanto o que têm hoje, acreditam que os esforços não seriam jogados fora, não perderiam a estabilidade, não teriam dificuldades em desenvolver novos relacionamentos com colegas, não observam como um desperdício de tempo dispendido nessa instituição e também entendem que não estariam deixando para trás o 
que foi investido, nem prejudicariam as suas vidas profissionais, assim como não demorariam para se acostumar com um novo emprego. Eles entendem que a liberdade pode ser afetada com essa mudança e que os ganhos ou perdas são relativos, dependem da situação e das escolhas que serão tomadas.

A última dimensão do comprometimento organizacional é o normativo. O comprometimento normativo se refere ao sentimento de obrigação de continuar trabalhando naquela instituição (MEYER; ALLEN, 1991; REGO, 2002; SANTOS; BEUREN, 2017). Nesse sentido, buscou observar como os professores observam a ideia de permanecer nessa instituição, isto é, qual o entendimento que eles têm sobre continuar trabalho naquela instituição como uma forma de retribuir ao que ela já fez por ele, se eles entendem que é uma obrigação, se eles se sentiriam injustos caso saíssem dessa instituição, se eles consideram que são necessários para essa instituição e, por fim, se a gratidão que eles têm por essas entidades é o que os mantém ligado a elas. Dessa forma, tem-se a Tabela 10 que demonstra as constatações sobre os aspectos que envolvem o comprometimento normativo.

\section{Tabela 10 - Comprometimento Organizacional Normativo}

\begin{tabular}{|c|c|}
\hline Subcategoria & Entrevistas \\
\hline \multirow[t]{9}{*}{ Retribuir } & $\begin{array}{l}\text { Não (...) eu como professora vendo minha força de trabalho e a instituição tem uma remuneração em troca, assim eu } \\
\text { presto serviço (1) }\end{array}$ \\
\hline & o trabalho é remunerado, não estamos lá de graça (2) \\
\hline & Sim (...) eu acho que se eu permanecer é por retribuir a essa instituição (3) \\
\hline & $\begin{array}{l}\text { Sim (...) eu valorizo muito o fato de eles terem me dado essa oportunidade de trabalho mesmo sem ter o nível de mestrado, } \\
\text { sem ter experiência, então eu sou muito grata a isso, e com certeza eu pondero isso (5) }\end{array}$ \\
\hline & Com certeza (...) eu tenho a consciência de o que eu faço tem essa contraprestação (7) \\
\hline & Sim (...) a universidade te formou e você deve pra universidade, então pense como um pagamento (8) \\
\hline & $\begin{array}{l}\text { Sim, hoje eu considero que seria uma forma de retribuir, pelo tempo de casa que a gente já tem e pelo crescimento } \\
\text { profissional que a instituição já nos proporcionou (9) }\end{array}$ \\
\hline & $\begin{array}{l}\text { Eu acho que sim, se o grupo é acolhedor, se o grupo é colaborativo, você tem que contribuir da mesma forma, com o } \\
\text { grupo e com novas pessoas que vão entrando e saindo do grupo, eu acho que ficar aqui é uma forma de retribuir isso (10) }\end{array}$ \\
\hline & Sim (...) estar aqui hoje eu penso que é um contributo também (11) \\
\hline \multirow[t]{11}{*}{ Obrigação } & Não (...) eu vejo como uma coisa que eu gosto e quero fazer, mas não uma obrigação (1) \\
\hline & $\begin{array}{l}\text { o fato de estar na sala de aula é um fato que me dá prazer, porque se for para viver só de dar aula com o salário que a } \\
\text { gente ganha enquanto professor universitário, você não suporta, não dá para se manter (2) }\end{array}$ \\
\hline & não considero uma obrigação (...) Não é algo que eu tenha que ficar lá, é por prazer mesmo, por gostar do ambiente (3) \\
\hline & Eu tenho um pouco desse comprometimento, mas é um comprometimento que faz parte da minha personalidade (4) \\
\hline & Não (...) enquanto estiver sendo benéfico para mim, eu permaneço lá (5) \\
\hline & eu estou lá por uma opção minha (6) \\
\hline & nada é obrigado, mas pela satisfação pessoal e pelo gosto pela formação e pela profissão que eu to levando (7) \\
\hline & Não (...) é satisfação, e isso é natural (...) foi por uma missão (8) \\
\hline & Não sinto uma obrigação perante a instituição, mas é pelo crescimento profissional que a gente tá trabalhando nela (9) \\
\hline & eu acho que não é uma obrigação, é algo que você faz por espontânea vontade (10) \\
\hline & Não, como uma obrigação não, eu estou aqui por prazer, porque eu amo fazer isso (11) \\
\hline \multirow[t]{8}{*}{ Injustiça } & Acho que não (...) ninguém é insubstituível (1) \\
\hline & $\begin{array}{l}\text { eu estaria sendo injusto (...) pelo aquilo que eu já tenha vivido lá, pelas experiências que eu tenha vivido com a instituição } \\
\text { (3) }\end{array}$ \\
\hline & Pelo o investimento que a universidade fez (...) eu considero um pouco injusto (4) \\
\hline & não seria uma injustiça porque a gente tem o livre-arbítrio de ir e vir (5) \\
\hline & eu não vejo isso como injusto não (6) \\
\hline & $\begin{array}{l}\text { Parcialmente, sim, pois foi ela que deu o apoio inicial pra gente começar na docência, então seria um pouco imparcial } \\
\text { com a instituição, seria imparcial da minha parte (9) }\end{array}$ \\
\hline & Acho que não, porque a gente não tem essa obrigação de trabalhar na instituição (10) \\
\hline & por tudo que a Universidade já me deu, já me proporcionou, eu acho que nesse momento eu não seria muito justa (11) \\
\hline \multirow{2}{*}{$\begin{array}{l}\text { Percepção de } \\
\text { necessidade } \\
\text { serviços }\end{array}$} & $\begin{array}{l}\text { Necessita (...) ela precisa de professores para dar aula, mas se não for eu que fizer isso, uma outra pessoa vai fazer de uma } \\
\text { forma melhor ou igual eu faça (1) }\end{array}$ \\
\hline & eu não acho que sou insubstituível (4) \\
\hline
\end{tabular}




\begin{tabular}{ll}
\hline & $\begin{array}{l}\text { Sim (...) poderia (...) participo do conselho de centro, conselho de campus e conselho universitário, e desenvolvo outros } \\
\text { trabalhos com outros colegas de outros cursos (8) }\end{array}$ \\
\cline { 2 - 2 } & não dos meus necessariamente, profissionais se acha até mais qualificados do que eu (...) eu não sou insubstituível (11) \\
\hline Gratidão & $\begin{array}{l}\text { Não é só gratidão que te mantém ligado, porque é um relacionamento profissional (...) Se eu tivesse a oportunidade de ir } \\
\text { para outra instituição ganhando mais, eu iria (2) }\end{array}$ \\
& Eu acho que não a gratidão que me mantém ligado a ela, mas isso faz parte (6) \\
& Gratidão (...)é o que mais me mantenha ligado, essa gratidão (8) \\
\hline Só a gratidão não, eu preciso corresponder com o meu trabalho (11) \\
\hline
\end{tabular}

Fonte: Elaborada pelos autores (2017).

Os professores universitários encaram continuar na instituição em que trabalham como uma forma de retribuir ao que ela já fez por eles $(3,5,7,8,9,10$ e 11). Eles têm valorizado o fato dessa instituição ter dado uma oportunidade de trabalho em um momento inicial na carreira (5) e também pelo fato de serem professores das instituições que eles mesmos se formaram (8 e 11). Outros entendem diferente (1 e 2), já que consideram que existe uma relação de trabalho formalizada, inclusive são remunerados para prestarem esse tipo de serviço.

Quando questionados se eles observam isso como uma obrigação, uma percepção geral foi de que não enxergam dessa forma $(1,2,3,4,5,6,7,8,9,10$ e 11). Entendem que é algo que eles gostam e querem fazer (1), é prazeroso (2, 3 e 11), é uma opção que eles fizeram (6 e 10) e permite o crescimento profissional.

A sensação de estarem sendo justos ou não caso saíssem de lá varia entre os entrevistados, alguns entendem que estariam sendo injustos $(3,4,9$ e 11$)$, outros entendem que não $(1,5,6$ e 10). A sensação de injustiça se justifica pelo fato de eles terem passado por diversas experiências naquela instituição (3), pelo investimento que a própria instituição já depositou no professor (4) e de ter apoiado no momento inicial da carreira (9). Outros entendem que ninguém é insubstituível (1) e também acreditam no direito de ir e vir (5).

Alguns dos entrevistados entendem que a instituição necessita dos seus serviços (1 e 8), outros já se mostraram de forma contrária (4 e 11). Para eles, ninguém é insubstituível (4 e 11), entendem que existem outros profissionais até mesmo mais qualificados (11).

Os professores compreendem que não é a gratidão que os mantêm ligados à sua instituição (2, 6 e 11), porque entendem que existe um relacionamento profissional (2). Apesar disso, temse também a percepção contrária, de que a gratidão é o que mantém o laço entre o professor e a instituição (8). Verifica-se, portanto, que a gratidão é um dos fatores que influencia os professores a permanecerem nas suas respectivas instituições, mas não é somente isso que justifica o vínculo (6).

Dessa forma, observa-se que os professores concebem que continuar naquela instituição é uma forma de retribuir ao que ela já fez por eles, mas não enxergam isso como uma obrigação, apesar de que alguns entendem que estariam sendo injustos caso saíssem de lá. Observam que não é a gratidão que os mantêm ligados a essa instituição. 
O estudo de Santos e Beuren (2017) indica a satisfação no trabalho influencia o comprometimento normativo, já que esses professores têm um sentimento positivo em relação ao seu trabalho (ALTAHAYNEH; KHASAWNEH; ABEDALHAFIZ, 2014) e, por isso, talvez julguem que permanecer na instituição seria uma forma de retribuir e não serem injustos, ainda que não observem como uma obrigação (MEYER; ALLEN; SMITH, 1993; REGO, 2002; SANTOS; BEUREN, 2017).

\subsection{O Capital Psicológico do Trabalho e a Satisfação e Comprometimento Organizacional}

Tendo em vista os pressupostos teóricos e as análises levantadas junto às entrevistas, verificou-se que existe uma relação entre o capital psicológico do trabalho e a satisfação e o comprometimento organizacional. Ainda que o objetivo deste trabalho não seja determinar essas relações, mas sim compreender de forma aprofundada como se constitui cada um desses constructos teóricos, elaborou-se a Figura 1, que representa o modelo teórico desses três constructos.

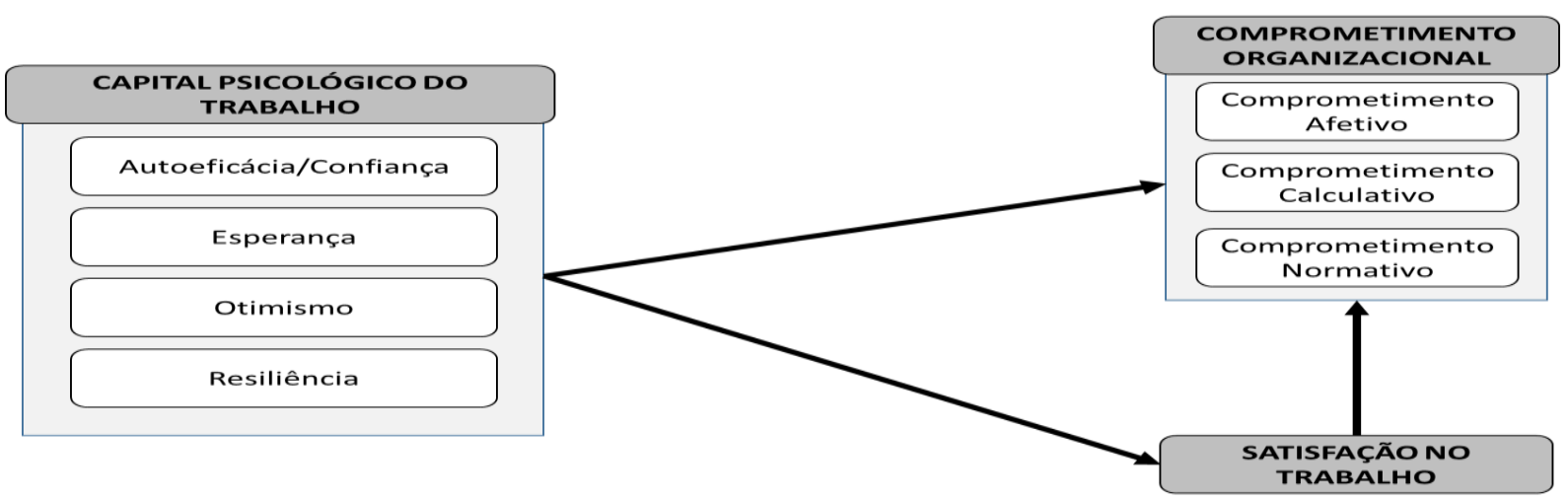

Figura 1 - Capital Psicológico do Trabalho e a Satisfação e Comprometimento Organizacional Fonte: Elaborada pelos autores (2017).

O capital psicológico do trabalho pode influenciar positivamente a satisfação e o comprometimento organizacional dos trabalhadores. Alguns estudos já encontraram evidências consistentes entre o capital psicológico e a satisfação e o comprometimento organizacional (LARSON; LUTHANS, 2006; LUTHANS et al., 2007; YOUSSEF; LUTHANS, 2007; AVEY et al., 2011).

As constatações desta pesquisa podem contribuir para se entender e justificar essa associação. Os professores, por exemplo, têm a confiança para assumir e colocar o esforço necessário diante de desafios (LUTHANS et al. 2007), quanto mais ele tiver essa sensação mais ele se mostraria comprometido com a organização. Os indivíduos esperançosos tendem a apresentar também um maior senso de autoeficácia (SNYDER et al., 2000), assim, é mister considerar que os professores que acreditam nos seus sonhos, e por isso buscam caminhos para 
atingir esses objetivos, podem ser mais comprometidos dentro da instituição. A crença de esperança leva ao otimismo, o qual move os indivíduos ao sucesso e à melhora a saúde física, psicológica e organizacional (LUTHANS, 2002), logo, seriam mais comprometidos. A aptidão de superar e se recompor frente à adversidade fortalece os indivíduos, o que representa a resiliência (LUTHANS; YOUSSEF, 2004).

Os professores se mostraram preparados para enfrentar diferentes adversidades, como demissões, perdas e mudanças, apresentaram confiança (autoeficácia) na possibilidade de superar os desafios, tendo a esperança e o otimismo que os seus objetivos e seus sonhos serão atingidos. Ao mesmo tempo, esses professores se mostraram confiantes, empolgados, dedicados, orgulhosos, contentes, responsáveis, dedicados com a instituição, o que demonstra que eles têm também elevado grau de comprometimento afetivo dentro dessas instituições.

Da mesma forma, a percepção positiva do capital psicológico desses professores pode justificar a satisfação que eles têm em exercer essa atividade. Os docentes apresentam um estado emocional agradável com seu trabalho e das atividades que exercem (LOCKE, 1969), essa satisfação pode ser consequência de um estado psicológico positivo.

Por último, a satisfação desses indivíduos pode estar associada ao comprometimento que eles têm com a universidade. Os docentes têm um sentimento positivo quanto às atividades que exercem (ALTAHAYNEH; KHASAWNEH; ABEDALHAFIZ, 2014), estão emocionalmente ligados e envolvidos com a instituição, por isso, sentem um desejo de permanecer nela (MEYERS; ALLEN, 1991). A ideia de permanecer na instituição seria uma forma de retribuir ao que ela já fez por eles (MEYER; ALLEN; SMITH, 1993; REGO, 2002; SANTOS; BEUREN, 2017).

\section{CONCLUSÃO}

O objetivo desse artigo foi de analisar como se constitui o capital psicológico do trabalho (autoeficácia, esperança, otimismo e resiliência) e a satisfação e o comprometimento organizacional (afetivo, calculativo e normativo) de professores universitários de Contabilidade. Para tanto, adotou-se um delineamento metodológico a partir de uma pesquisa qualitativa, em que se utilizou da análise de discurso para entender em profundidade como se constitui estes três constructos teóricos com os professores universitários de Contabilidade.

Realizadas as entrevistas, concluiu-se que os professores demonstram confiança para assumir e colocar o esforço necessário para assumir desafios, já que demonstraram aptidão para a resolução de problemas; enxergam os desafios como uma forma de os deixar mais forte, encaram novos procedimentos como uma coisa instigante. No que se refere ao atributo 
esperança, eles acreditam que seus sonhos serão realizados e, para isso, buscam descobrir caminhos para atingir os seus objetivos e as suas metas. Esses indivíduos apresentam um estado psicológico otimista, devido a isso, acreditam em uma situação melhor no futuro. Os professores se sentem preparados para enfrentar situações adversas, como uma demissão, perdas e mudanças. Acreditam que muitos desafios são mais difíceis no início, mas pela experiência e superação se tornam mais fáceis de se recompor (LUTHANS et al., 2007; DEMO; OLIVEIRA; COSTA, 2017).

Os quatro elementos do capital psicológico (autoeficácia, esperança, otimismo e resiliência) parecem ser inerentes à realidade da profissão de professor, justificando as motivações desses indivíduos (YOUSSEF; LUTHANS, 2007), o que permite contribuir para gerar benefícios para as instituições em que eles estão inseridos (VILAÇA; MÓNICO; CASTRO, 2012).

Esses professores universitários se mostraram satisfeitos com o espírito de colaboração de colegas, com o grau de interesse que as tarefas despertam, da oportunidade de fazer esse tipo de trabalho e do entendimento com os seus chefes. Eles estão felizes com o seu trabalho (SANTOS; BEUREN, 2017) e têm o prazer profissional de exercer essa atividade (ALTAHAYNEH; KHASAWNEH; ABEDALHAFIZ, 2014).

Os professores se sentem confiantes com a instituição, se sentem empolgados, fiéis, apegados, orgulhosos, contentes, responsáveis, dedicados e envolvidos com a instituição, o que caracteriza o comprometimento afetivo destes profissionais. No que se refere ao comprometimento calculativo, observou-se que não são os custos de sair dessa instituição que mantêm esses professores ligados a ela (MEYER; ALLEN, 1991; REGO, 2002), visto que eles consideram que não teriam "gastos" ou perderiam muito caso saíssem de lá, como um bom salário, os esforços dispendidos, a estabilidade e o que foi investido na instituição. Por último, no tocante ao comprometimento normativo, observa-se que os professores entendem que continuar naquela instituição é uma forma de retribuir ao que ela já fez por eles, mas não enxergam isso como uma obrigação, ainda que sintam-se injustos caso saíssem de lá.

O capital psicológico do trabalho pode estar associado à satisfação e ao comprometimento organizacional desses professores. Os professores demonstram confiança na superação dos desafios, têm esperança e otimismo que os sonhos e objetivos serão atingidos, ao mesmo tempo que se sentem envolvidos emocionalmente e tem a ideia de estarem retribuindo a essas instituições. Da mesma forma, se mostram satisfeitos e, em virtude disso, comprometidos, não por julgaremque isso seja uma obrigação, mas por gostarem e sentirem satisfeitos em realizar 
o tipo de trabalho que fazem (LARSON; LUTHANS, 2006; LUTHANS et al., 2007; YOUSSEF; LUTHANS, 2007; AVEY et al., 2011).

O desenvolvimento dos recursos humanos é fundamental para o sucesso organizacional e para a criação de uma vantagem competitiva durável (IDRIS; MANGANARO, 2017). Os professores enfrentam desafios diários e complexos na sua profissão, representam um valor agregado para toda a sociedade, portanto, é importante que se compreenda sobre as construções do capital psicológico desses indivíduos para melhorar os resultados, profissionais e pessoais deles e das instituições em que eles estão inseridos.

Como limitação de pesquisa, tem-se não ter realizado também uma abordagem quantitativa com esses professores, haja vista que isso poderia ter aumentado o número de indivíduos e também sugerido associações estatísticas entre os três constructos teóricos abordados. Todavia, o escopo central era tentar compreender de forma aprofundada e buscar explicações sobre como se constitui esses constructos. Dessa forma, sugere-se como pesquisas futuras buscar adaptar essa pesquisa de forma quantitativa e verificar se existe associação entre o capital psicológico e a satisfação e o comprometimento organizacional.

\section{REFERENCIAS}

ALBASSAMI, F. A.; AL-MESHAL, S. A.; BAILEY, A. A. An investigation of internal marketing and its effects on employees in the banking sector in Saudi Arabia. Journal of Financial Services Marketing, v. 20, n. 3, p. 176-190, 2015.

ALSHITRI, K. I. An investigation of factors affecting job satisfaction among R\&D center employees in Saudi Arabia. Journal of Human Resources Management Research, v. 2013, p. 1, 2013.

ALTAHAYNEH, Z. L.; KHASAWNEH, A.; ABEDALHAFIZ, A. Relationship between organizational justice and job satisfaction as perceived by Jordanian physical education teachers. Asian Social Science, v. 10, n. 4, p. 131, 2014.

ANDRADE, T. F. D.; BARBOSA, S. D. C.; SOUZA, S.; MOREIRA, J. S. Valores humanos e satisfação no trabalho de professores e servidores técnico-administrativos de uma universidade pública. Revista Psicologia Organizações e Trabalho, v. 15, n. 4, p. 397-406, 2015.

AVEY, J. B.; LUTHANS, F.; JENSEN, S. M. Psychological capital: A positive resource for combating employee stress and turnover. Human resource management, v. 48, n. 5, p. $677-$ 693, 2009.

AVEY, J. B.; REICHARD, R. J.; LUTHANS, F.; MHATRE, K. H. Meta-analysis of the impact of positive psychological capital on employee attitudes, behaviors, and performance. Human resource development quarterly, v. 22, n. 2, p. 127-152, 2011.

BAKKER, A. B.; SCHAUFELI, W. B.; LEITER, M. P.; TARIS, T. W. Work engagement: An emerging concept in occupational health psychology. Work \& Stress, v. 22, n. 3, p. 187200, 2008. 
BOUZADA, V. C. P. C.; KILIMNIK, Z. M.; OLIVEIRA, L. C. V. Professor iniciante: desafios e competências da carreira docente de nível superior e inserção no mercado de trabalho. Revista de Carreiras e Pessoas (ReCaPe). v. 2, n. 1, p. 1-18, 2012.

BULUC, B.; GUNES, A. M. Relationship between Organizational justice and Organizational Commitment in primary schools. Anthropologist, v. 18, n. 1, p. 145-152, 2014.

CASIMIR, G. et al. The relationships amongst leader-member exchange, perceived organizational support, affective commitment, and in-role performance: A social-exchange perspective. Leadership \& Organization Development Journal, v. 35, n. 5, p. 366-385, 2014.

DEMO, G.; OLIVEIRA, A. F.; COSTA, A. C. Resiliência no trabalho: revisão bibliométrica sistemática no contexto brasileiro e itinerários da produção nacional. Revista Psicologia Organizações e Trabalho, v. 17, n. 3, p. 180-189, 2017.

EISENBERGER, R.; HUNTINGTON, R.; HUTCHISON, S.; SOWA, D. Perceived organizational support. Journal of Applied Psychology, v. 71, n. 3, p. 500, 1986.

FERGUSON, K. L.; REIO JR, T. G. Human resource management systems and firm performance. Journal of Management Development, v. 29, n. 5, p. 471-494, 2010.

GONG, Y. et al. Human resources management and firm performance: The differential role of managerial affective and continuance commitment. Journal of Applied Psychology, v. 94, n. 1, p. 263, 2009.

GONZÁLEZ, T. F.; GUILLEN, M.. Organizational commitment: A proposal for a wider ethical conceptualization of 'normative commitment'. Journal of Business Ethics, v. 78, n. 3, p. 401-414, 2008.

IDRIS, A. M.; MANGANARO, M. Relationships between psychological capital, job satisfaction, and organizational commitment in theSaudi oil and petrochemical industries. Journal of Human Behavior in the Social Environment, v. 27, n. 4, p. 251-269, 2017.

JAROS, S. A critique of normative commitment in management research. Management Research Review, v. 40, n. 5, p. 517-537, 2017

LACOMBE, B. M. B. O aluno de administração de empresas, o trabalho e a construção da carreira profissional: contribuições de um estudo na Grande São Paulo. ANAIS: XXVI ENANPAD. Salvador: Anpad. 2002.

LAPOINTE, É.; VANDENBERGHE, C.; BOUDRIAS, J. Psychological contract breach, affective commitment to organization and supervisor, and newcomer adjustment: A threewave moderated mediation model. Journal of Vocational Behavior, v. 83, n. 3, p. 528-538, 2013.

LARSON, M.; LUTHANS, F. Potential added value of psychological capital in predicting work attitudes. Journal of leadership \& organizational studies, v. 13, n. 1, p. 45-62, 2006.

LLORENS, S.; SCHAUFELI, W.; BAKKER, A.; SALANOVA, M. Does a positive gain spiral of resources, efficacy beliefs and engagement exist?. Computers in human behavior, v. 23, n. 1, p. 825-841, 2007.

LOCKE, E. A. What is job satisfaction?. Organizational behavior and human performance, v. 4, n. 4, p. 309-336, 1969. 
LUTHANS, F. The need for and meaning of positive organizational behavior. Journal of organizational behavior, v. 23, n. 6, p. 695-706, 2002.

LUTHANS, F.; AVEY, J. B.; AVOLIO, B. J.; PETERSON, S. J. The development and resulting performance impact of positive psychological capital. Human resource development quarterly, v. 21, n. 1, p. 41-67, 2010.

LUTHANS, F.; AVOLIO, B. J.; AVEY, J. B.; NORMAN, S. M. Positive psychological capital: Measurement and relationship with performance and satisfaction. Personnel psychology, v. 60, n. 3, p. 541-572, 2007.

LUTHANS, F.; YOUSSEF, C. M. Human, social, and now positive psychological capital management: Investing in people for competitive advantage. Organizational dynamics, $v$. 33, n. 2, p. 143-160, 2004.

MASTEN, A. S. Ordinary magic: Resilience processes in development. American psychologist, v. 56, n. 3, p. 227, 2001.

MARCOS, C., VOGT, M., \& DA CUNHA, P. R. Capital Psicológico no Trabalho e a Intenção de Rotatividade de Auditores Independentes. USP International Conference in Accounting, São Paulo, SP, Brasil, XVII.

MEYER, J. P.; ALLEN, N. J. A three-component conceptualization of organizational commitment. Human resource management review, v. 1, n. 1, p. 61-89, 1991.

MEYER, J. P.; ALLEN, N. J.; SMITH, C. A. Commitment to organizations and occupations: Extension and test of a three-component conceptualization. Journal of applied psychology, v. 78, n. 4, p. 538, 1993.

MEYER, J. P. et al. Affective, continuance, and normative commitment to the organization: A meta-analysis of antecedents, correlates, and consequences. Journal of vocational behavior, v. 61, n. 1 , p. 20-52, 2002.

MOWDAY, R. T.; STEERS, R. M.; PORTER, L. W. The measurement of organizational commitment. Journal of vocational behavior, v. 14, n. 2, p. 224-247, 1979.

NOGUEIRA, C. Análise do discurso. 2001.

PAIVA, L. E. B.; LIMA, T. C. B.; OLIVEIRA, T. S.; PITOMBEIRA, S. S. R. Percepção da influência das políticas e práticas de recursos humanos na satisfação com o trabalho. Revista Pensamento Contemporâneo em Administração, v. 11, n. 1, p. 55, 2017.

PAULA, A. P. V.; QUEIROGA, F. Satisfação no trabalho e clima organizacional: a relação com autoavaliações de desempenho. Revista Psicologia Organizações e Trabalho, v. 15, n. 4, p. 362-373, 2015.

POLIZZI FILHO, A. O impacto de bem-estar no trabalho e de capital psicológico sobre intenção de rotatividade: um estudo com professores. 2011. 113 f. Dissertação (Mestrado em Gestão de organizações) - Universidade Metodista de São Paulo, São Bernardo do Campo, 2011.

PORTER, L. W. et al. Organizational commitment, job satisfaction, and turnover among psychiatric technicians. Journal of applied psychology, v. 59, n. 5, p. 603, 1973.

RAUPP, F. M, BEUREN. I. M. Metodologia de pesquisa aplicado as ciências sociais. In: BEUREN, I. M, Org. Como elaborar trabalhos monográficos em contabilidade. 3 ed. São Paulo: Atlas, 2009. 
REGO, A. Comprometimento afectivo dos membros organizacionais: o papel das percepções de justiça. Revista de Administração Contemporânea, v. 6, n. 2, p. 209-241, 2002.

REGO, A.; SOUTO, S. A percepção de justiça como antecedente do comprometimento organizacional: um estudo luso-brasileiro. Revista de administração contemporânea, v. 8, n. 1, p. 151-177, 2004.

RHOADES, L.; EISENBERGER, R.; ARMELI, S. Affective commitment to the organization: The contribution of perceived organizational support. Journal of applied psychology, v. 86, n. 5, p. 825, 2001

ROELEN, C. A. M.; KOOPMANS, P. C.; GROOTHOFF, J. W. Which work factors determine job satisfaction? Work, v. 30, n. 4, p. 433-439, 2008.

RUEDA, F. J. M. Análise fatorial confirmatória da Escala de Satisfação no Trabalho nas versões de 25 e 15 itens. Revista Psicologia Organizações e Trabalho, v. 15, n. 1, p. 82-88, 2015.

SALLAN, J. M. et al. Estudio de la relación entre el compromiso organizativo y la intención de abandonar la organización: Modelo de dos componentes de compromiso de continuidad. Cuadernos de gestión, v. 10, n. 2, 2010.

SANTOS, V.; BEUREN, I. M. (2017). Influência da Percepção de Justiça Organizacional no Comprometimento e Satisfação no Trabalho de Professores Universitários. USP

International Conference in Accounting, São Paulo, SP, Brasil, XVII.

SCHAUFELI, W. B.; BAKKER, A. B. Job demands, job resources, and their relationship with burnout and engagement: A multi-sample study. Journal of organizational Behavior, v. 25, n. 3, p. 293-315, 2004.

SIQUEIRA, M. M. M.; GOMIDE JUNIOR, S. Vínculos do indivíduo com o trabalho e com a organização. Psicologia, organizações e trabalho no Brasil, v. 2, p. 317-348, 2004.

SIQUEIRA, M. M. M.; PADOVAM, V. A. R. Bases teóricas de bem-estar subjetivo, bemestar psicológico e bem-estar no trabalho. Psicologia: teoria e pesquisa, v. 24, n. 2, p. 201209, 2008.

SIQUEIRA, M.; MARIA, M.; SHOITI KUNIYOSHI, M.; CAVALCANTE, M. M.

Engajamento, bem-estar no trabalho e capital psicológico: um estudo com profissionais da área de gestão de pessoas. Pensamento \& Realidade, v. 29, n. 4, 2014.

SNYDER, C. R.; ILARDI, S.; MICHAEL, S. T.; CHEAVENS, J. Hope theory: Updating a common process for psychological change. In C. R. SNYDER; R. E. INGRAM (Eds.), Handbook of psychological change: Psychotherapy processes \& practices for the 21st century (pp. 128-153). Hoboken, NJ: John Wiley. 2000.

SNYDER, C. R.; SHOREY, H. S.; CHEAVENS, J.; PULVERS, K. M.; ADAMS III, V. H.; Wiklund, C. Hope and academic success in college. Journal of educational psychology, v. 94, n. 4, p. 820, 2002.

SOUZA, W. S.; CONCEIÇÃO, G. S. A influência do capital psicológico no bem estar de trabalhadores: estudo com operadores de caixa de supermercados. RAUnP-ISSN 1984-4204, v. 5, n. 2, p. 9-22, 2013.

SOUZA, W. S.; SIQUEIRA, M. M. M.; MARTINS, M. C. F. Análise da interdependência do capital psicológico, percepções de suporte e bem-estar no trabalho. Revista Administração em Diálogo-RAD, v. 17, n. 2, 2015. 
STAJKOVIC, A. D.; LUTHANS, F. Self-efficacy and work-related performance: A metaanalysis. Psychological bulletin, v. 124, n. 2, p. 240, 1998.

SULIMAN, A.; ILES, P. Is continuance commitment beneficial to organizations?

Commitment-performance relationship: A new look. Journal of Managerial Psychology, v. 15, n. 5, p. 407-422, 2000.

VANDENBERGHE, C.; MIGNONAC, K.; MANVILLE, C. When normative commitment leads to lower well-being and reduced performance. human relations, v. 68, n. 5, p. 843-870, 2015.

VILAÇA, I.; MÓNICO, L. S. M.; CASTRO, F. V. Da espiritualidade organizacional ao capital psicológico individual: qual o papel da liderança autêntica? International Journal of Developmental and Educational Psychology, v. 4, n. 1, p. 281-289, 2012.

WANG, Q. et al. Organizational career growth and subsequent voice behavior: The role of affective commitment and gender. Journal of Vocational Behavior, v. 84, n. 3, p. 431-441, 2014.

YOUSSEF, C. M.; LUTHANS, F. Positive organizational behavior in the workplace: The impact of hope, optimism, and resilience. Journal of management, v. 33, n. 5, p. 774-800, 2007. 